Review Article

\title{
Biomarkers to Improve Diagnosis and Monitoring of Obstructive Sleep Apnea Syndrome: Current Status and Future Perspectives
}

\author{
Konstantinos Archontogeorgis, ${ }^{1}$ Evangelia Nena, ${ }^{2}$ \\ Nikolaos Papanas, ${ }^{3}$ and Paschalis Steiropoulos ${ }^{1,4}$ \\ ${ }^{1}$ Department of Pneumonology, Medical School, Democritus University of Thrace, 68100 Alexandroupolis, Greece \\ ${ }^{2}$ Laboratory of Hygiene and Environmental Protection, Medical School, Democritus University of Thrace, \\ 68100 Alexandroupolis, Greece \\ ${ }^{3}$ Second Department of Internal Medicine, Medical School, Democritus University of Thrace, 68100 Alexandroupolis, Greece \\ ${ }^{4}$ Sleep Unit, Department of Pneumonology, Medical School, Democritus University of Thrace, 68100 Alexandroupolis, Greece
}

Correspondence should be addressed to Paschalis Steiropoulos; pstirop@med.duth.gr

Received 30 June 2014; Accepted 23 October 2014; Published 27 November 2014

Academic Editor: Thomas Penzel

Copyright (C) 2014 Konstantinos Archontogeorgis et al. This is an open access article distributed under the Creative Commons Attribution License, which permits unrestricted use, distribution, and reproduction in any medium, provided the original work is properly cited.

Obstructive sleep apnea syndrome (OSAS) is characterized by recurrent episodes of upper airway collapse associated with oxygen desaturation and sleep disruption. It is proposed that these periodic changes lead to molecular variations that can be detected by assessing serum biomarkers. Studies have identified inflammatory, oxidative, and metabolic perturbations attributable to sleepdisordered breathing. Given that OSAS is associated with increased cardiovascular and cerebrovascular morbidity, the ideal biomarker should enable timely recognition with the possibility of intervention. There is accumulating data on the utility of serum biomarkers for the evaluation of disease severity, prognosis, and response to treatment. However, current knowledge is limited by data collection techniques, disease complexity, and potential confounding factors. The current paper reviews the literature on the use of serum biomarkers in OSAS. It is concluded that the ideal serum biomarker still needs to be discovered, while caution is needed in the interpretation of hitherto available results.

\section{Introduction}

Obstructive sleep apnea syndrome (OSAS) is characterized by recurrent episodes of upper airway collapse associated with oxygen desaturation and sleep fragmentation [1]. It is a common disorder, with prevalence estimated at $4 \%$ for men and $2 \%$ for women among adults in the Western countries [2]. Considering the rising incidence of obesity, a recognized risk factor for OSAS, the prevalence of this condition will probably increase. OSAS is associated with increased risk for cardiovascular disease [3] and cerebrovascular morbidity [4].

Oxygen desaturation accompanying apneic events, negative intrathoracic pressure, arousals induced by upper airway obstruction, and repeated activation of the sympathetic system may cause abnormal activation of neural, humoural, thrombotic, metabolic, and inflammatory responses, thereby promoting atherosclerosis $[5,6]$. The potential etiological mechanisms may include endothelial dysfunction, oxidative stress, inflammation, and disorders of coagulation and lipid metabolism [7].

OSAS is diagnosed by polysomnography (PSG) and is treated by Continuous Positive Airway Pressure (CPAP) application, oral appliances, surgery, and weight loss. However, it often remains undiagnosed and untreated. Indeed, recent investigations have shown that the probable reason for this underdiagnosis is lack of physicians' awareness [8]. Furthermore, patients are often reluctant to undergo overnight PSG and follow the appropriate therapy.

A biomarker is defined as a characteristic that is objectively measured and evaluated as an indicator of normal biologic processes, pathogenic processes, or pharmacologic response to a therapeutic intervention [9]. In the case of 
OSAS, the ideal biomarker should be useful for the following: diagnosis, assessing disease burden and severity, and evaluating response to treatment [10]. To ensure diagnostic accuracy, a biomarker should yield both high sensitivity and specificity. Such diagnostic performance would limit the need of PSG, an expensive and laborious modality, at least in some patients. For the evaluation of disease severity and response to treatment, a biomarker should be implicated in the pathogenesis of complications and should respond to therapy. Variations in biomarker levels as response to therapy would then reflect reduction of complications. Additional aspects should include low cost and facility in use, as well as the ability to simultaneously evaluate multiple pathogenic pathways.

The aim of this review is to summarize current knowledge on the utility of serum biomarkers in OSAS.

\section{Search Strategy}

We performed an electronic search in PubMed, EMBASE, and Google Scholar, using combinations of the following keywords: OSAS, biomarkers, serum, inflammation, oxidative stress, and metabolic. References from systematic reviews and meta-analyses were also screened for relevant studies. The search included all types of articles written in English up to April 2014. Cross-sectional, case control, and cohort studies with comparison group data were included in this review. Studies with historical controls, case series, and case reports were excluded and also studies published in any language other than English were excluded.

Regarding inflammatory markers a total of 229 studies were initially considered ( 69 for CRP, 43 for TNF- $\alpha, 16$ for IL-8, 49 for IL-6, 25 for cell adhesion molecules, and 27 for fibrinogen) and 59 were finally included in this review (16 for CRP, 13 for TNF- $\alpha$, 5 for IL-8, 11 for IL- 6,6 for cell adhesion molecules, and 8 for fibrinogen). A total of 42 studies were revised on the relationship between OSAS and oxidative stress (10 for antioxidant capacity, 8 for 8 -isoprostane, 8 for malondialdehyde, 8 for total antioxidant status, and 8 for paraoxonase) and 18 of them were included in the present review (3 for antioxidant capacity, 4 for 8-isoprostane, 5 for total antioxidant status, and 6 for paraoxonase). Our search regarding metabolic markers included 117 studies (27 for hemoglobin A1c, 47 for leptin, 36 for adiponectin, and 7 for resistin) and 29 studies were finally included in the current review (11 for hemoglobin Alc, 6 for leptin, 9 for adiponectin, and 3 for resistin).

\section{Inflammatory Markers}

A variety of studies have implicated OSAS as an important risk factor in the development of cardiovascular disease [3]. Although it is postulated that sleep deprivation and hypoxemia may contribute to the etiology of cardiovascular events, the exact mechanisms need further elucidation [11, 12].

According to one hypothesis, OSAS-induced hypoxic stress may increase circulating levels of biochemical mediators of inflammation. On the other hand, there is increased prevalence of obesity among patients with OSAS, and previous evidence suggests that adipose tissue can produce proinflammatory factors, such as C-reactive protein (CRP), tumor necrosis factor- $\alpha$ (TNF- $\alpha$ ), interleukin-6 (IL-6), and interleukin-8 [13-16].

3.1. CRP. CRP is a marker of inflammation that is mainly produced by the liver in response to IL-6. Increased CRP levels are identified as consequence of trauma or infection. Data suggests an active role in the atherogenic process mediated by the expression of adhesion molecules and monocyte activation [17]. Moreover, increased levels of CRP are recognized as an independent risk factor of future cardiovascular events among healthy subjects, as well as in patients with known cardiovascular disease $[18,19]$.

The relationship between OSAS and CRP has been the subject of various studies with contradictory results. Considerable evidence supports an independent association between serum CRP levels and OSAS [20]. In a comparison of 22 otherwise healthy OSAS patients with 20 subjects matched for age and body mass index (BMI) without OSAS, CRP levels were significantly higher among the former ( 0.33 versus $0.09 \mathrm{mg} / \mathrm{dL}, P<0.0003$ ), and they were independently associated with disease severity [21]. Similar results were reported by Hayashi et al. [22]. Among 60 patients, repetitive hypoxemia was significantly correlated with high sensitivityCRP (hs-CRP) and appeared to be a fundamental determinant for this molecule. CRP levels were also correlated with indices of nocturnal hypoxia (average or minimum $\mathrm{SpO}_{2}$ during sleep), suggesting that hypoxia is probably the major contributor in the activation of inflammation in OSAS [23].

In another study on 76 patients, hs-CRP levels between a group of OSAS patients and a control group matched for age, sex, and BMI were compared. Hs-CRP levels were higher in the OSAS group in comparison to controls and were positively correlated with BMI $(r=0.376, P=0.001)$ and apnea-hypopnea index (AHI) $(r=0.280, P=0.014)$. Multiple regression analysis demonstrated an association of hs-CRP levels with AHI $(F=3.293, P=0.033)$, which was independent of obesity [24].

In a comparison between 161 OSAS patients and 61 controls, serum CRP levels were significantly higher in the OSAS group $(<1 \mathrm{mg} / \mathrm{dL}$ in controls versus $2 \mathrm{mg} / \mathrm{dL}$ in OSAS patients, $P=0.001)$, and AHI was an independent predictor for CRP. Even though OSAS patients had higher age and BMI than controls, the association between CRP levels and AHI remained significant after adjustment for these variables $(P<0.001)$, while this association was not significant when additional factors (cardiovascular disease, smoking, systolic blood pressure) were considered [25].

Yokoe et al. [26] have found that CRP levels in OSAS patients were higher when compared with obese control subjects and were decreased after 30 days of CPAP therapy. Serum levels of cardiovascular risk factors, including hs-CRP, were decreased after 6 months of CPAP application in a group of OSAS patients $(P=0.03)$ [27]. However, Kohler et al. [28] have found that 4 weeks of CPAP treatment had no beneficial effect on CRP levels in a group of patients with moderatesevere OSAS and comorbidities.

In a meta-analysis of 14 studies with a total of 771 patients, CRP levels ranged from 0.18 to $0.85 \mathrm{mg} / \mathrm{dL}$ before CPAP 
treatment and from 0.10 to $0.72 \mathrm{mg} / \mathrm{dL}$ after CPAP therapy [29]. The pooled mean difference was 0.14 (95\% confidence interval (95\% CI) $0.08-0.20, P<0.00001)$ [29]. A further meta-analysis of 30 studies assessing the relationship between CRP and OSAS confirmed that CRP was higher in OSAS patients compared with controls (pooled mean difference 1.77) [30].

Conversely, several authors have failed to demonstrate a relationship between CRP levels and OSAS [31,32]. In other cases, this association was not significant after adjustment for obesity [12, 23]. In an analysis of 156 subjects with OSAS [31], 39 subjects with upper airway resistance syndrome, and 54 controls, serum CRP levels were normal in all groups and only BMI was significantly associated with high CRP values $(P<0.001)$. Ryan et al. [32] have compared serum CRP levels in a group of non-OSAS subjects with those of a group of mild/moderate and a group of severe OSAS patients matched for BMI and with a group of more obese OSAS patients. CRP levels were similar among the BMI-matched groups, but they were significantly increased in the more obese group $(P<0.05)$. Multivariate analysis of all subjects demonstrated that BMI, but not AHI, was an independent predictor of CRP levels. In the same study, 6 weeks of CPAP treatment did not alter serum CRP levels. Similarly, in a cohort of 454 untreated OSAS patients, OSAS severity was an independent predictor of CRP levels but interacted with obesity and thus was found only in obese patients [33].

The finding of increased serum CRP levels in OSAS patients and its association with disease severity may reflect the risk of developing cardiovascular events or the presence of subclinical atherosclerosis. Therefore, therapeutic interventions that aim at decreasing serum CRP levels may have a protective role for future cardiovascular and cerebrovascular complications.

3.2. TNF- $\alpha$. TNF- $\alpha$ is a proinflammatory cytokine produced by monocytes/macrophages during acute inflammation [34]. It participates in a wide spectrum of signaling events that lead to necrosis or apoptosis [34]. It is also involved in sleep regulation and has been positively correlated with excessive daytime sleepiness, nocturnal sleep disturbance, and hypoxia [35].

High serum levels of TNF- $\alpha$ have been shown to be produced by monocytes of OSAS patients [36]. Additionally, previous studies have demonstrated increased levels of TNF$\alpha$ in such patients during the morning and immediately after the first episode of obstructive apnea. Several datasets have confirmed the relationship between increased serum TNF$\alpha$ levels and OSAS [37, 38]. Steiropoulos et al. [23] found higher TNF- $\alpha$ levels in a group of OSAS patients compared to a group of BMI-matched control subjects $(6.72 \pm 3.72$ versus $3.94 \pm 1.34 \mathrm{pg} / \mathrm{mL}, P<0.001)$ [23]. Serum TNF- $\alpha$ was positively correlated with neck circumference $(r=0.452$, $P<0.001)$, AHI $(r=0.391, P=0.002)$, and oxygen desaturation index (ODI) $(r=0.384, P=0.002)$. Similar results were observed by Ciftci et al. [39].

In a comparison between 26 subjects with mild OSAS, 54 subjects with moderate/severe OSAS, and 40 controls, matched for age and BMI, TNF- $\alpha$ levels were significantly increased in the moderate/severe group, as compared with the other patients $(22.83 \pm 3.85$ for moderate/severe OSAS versus $14.42 \pm 3.29$ for mild OSAS versus $12.53 \pm 3.48 \mathrm{pg} / \mathrm{mL}$ for controls, $P<0.01$ ) [40]. Serum TNF- $\alpha$ levels were significantly correlated with carotid intima-media thickness ( $r=0.53, P<0.01)$, an early marker of atherosclerosis [40].

In another work [36], serum TNF- $\alpha$ levels and its spontaneous production by monocytes were increased in OSAS patients, as compared with obese subjects $(P<0.0005$ and $P<0.0001$, resp. $)$ and healthy individuals $(P<0.0001$ and $P<0.0001$, resp.) and were increased in parallel with disease severity. Interestingly, both spontaneous production and serum concentration of TNF- $\alpha$ were independently associated with duration of hypoxia during total sleep time, and they were decreased after one month of CPAP application [36]. Moreover, prior evidence demonstrated that increased levels of serum TNF- $\alpha$ can be attenuated after CPAP treatment $[41,42]$.

In a meta-analysis of pooled data from 9 studies with a total of 209 patients, mean TNF- $\alpha$ levels ranged from 1.40 to $50.24 \mathrm{pg} / \mathrm{mL}$ before CPAP treatment and 1.80 to $28.63 \mathrm{pg} / \mathrm{mL}$ after CPAP application. The pooled mean difference was 1.14 (95\% CI $0.12-2.15, P=0.03$ ) [29]. Another metaanalysis of 19 studies concluded that TNF- $\alpha$ serum levels were increased in OSAS patients in comparison to nonapneic controls (pooled mean difference 1.03) [30].

However, there is also evidence that there may be no difference in serum TNF- $\alpha$ among OSAS patients compared with controls, before and after therapy with CPAP $[43,44]$. Guasti et al. [44] compared TNF- $\alpha$ serum levels and production from peripheral blood mononuclear cells between 16 OSAS patients and 11 controls matched for cardiovascular risk factors, except obesity. Serum TNF- $\alpha$ was normal in both groups, and production from peripheral blood mononuclear cells was similar between groups. Treatment with CPAP for 12 weeks did not alter TNF- $\alpha$ serum levels [44]. Obviously, obesity may represent the primary confounding factor affecting the levels of TNF- $\alpha$ in these works. Indeed, macrophages of adipose tissue can also secrete TNF- $\alpha$ [45].

Even though there is a role for OSAS in promoting inflammation among obese individuals, possibly mediated by $\mathrm{TNF}-\alpha$, this interaction is quite complex and merits further study. This increased production of proinflammatory cytokines may affect patient outcomes, especially regarding increased frequency of cardiovascular and cerebrovascular complications associated with OSAS.

3.3. IL-8. IL-8 is a chemokine produced by macrophages and other cell types, such as epithelial cells, airway smooth muscle cells, and endothelial cells [46]. It has been demonstrated that hypoxia can positively affect the expression and production of this chemokine [47]. Previous reports have examined the expression of IL-8 in individuals with OSAS. Ohga et al. [48] have compared IL- 8 levels of 20 OSAS patients before and after CPAP treatment and 10 control subjects matched for age and BMI. IL-8 levels in the OSAS group were significantly higher than those in the control group $(P<0.05)$ [48]. A significant correlation between IL-8 levels and desaturation magnitude was observed $(r=0.69, P<0.001)$, while 
a positive correlation with apnea index was also suggested ( $r=0.51, P=0.004)$. CPAP treatment for at least 8 months decreased levels of this chemokine in the OSAS group [48].

Oyama et al. [49] have included 32 patients with OSAS and metabolic syndrome, finding that IL-8 serum levels were diminished after three months of CPAP treatment. In another study, IL-8 levels were increased in 25 severe OSAS patients when compared to 17 healthy individuals matched for age and BMI $(198.8 \pm 4.76$ versus $180.83 \pm 3.38 \mathrm{pg} / \mathrm{mL}$, resp., $P<0.005)$ [50].

However, negative findings have been reported as well [44]. In a comparison of 16 OSAS subjects with 11 controls, both IL-8 serum levels and its release from neutrophils were similar between both groups [44]. Moreover, 12 weeks of CPAP therapy did not influence serum concentration of cytokines [44]. Additionally, an enquiry into the effects of intermittent hypoxia in healthy subjects found no increased levels in IL-8 [51]. The authors concluded that a more substantial or a different pattern of hypoxia may be necessary for the initiation of systemic inflammation [51]. Alternatively, any increase in serum markers of inflammation in OSAS could be more related to other factors, such as obesity or night-time arousals [51].

In summary, hypoxic events induced by OSAS increase serum levels of IL-8, a risk factor of cardiovascular disorders. By reducing this chemokine, CPAP might represent an efficacious way of reducing cardiovascular complications associated with OSAS.

3.4. IL-6. IL-6 is a circulating cytokine produced by a variety of cells, including macrophages and lymphocytes [52]. It is a major initiator of the acute phase response and the principal regulator of the hepatic CRP production. Available data on IL-6 levels are often conflicting. Indeed, some groups have reported increased levels in OSAS, while others have demonstrated that obesity per se rather than OSAS was associated with systemic inflammation [23, 26, 39, 41, 43]. Specifically, IL-6 levels are higher in obesity, and their production is 2-3 times higher in visceral fat compared with subcutaneous fat $[53,54]$. Additionally, $15-30 \%$ of the circulating levels come from fat tissue [54].

Liu et al. [38] compared IL-6 levels in 22 OSAS patients and 16 normal controls. Plasma IL- 6 levels of OSAS patients were significantly higher in comparison with controls (50.67 \pm 4.70 versus $12.69 \pm 2.75 \mathrm{pg} / \mathrm{mL}$, resp.) [38]. A positive correlation was observed between the cytokine and percentage of time of apnea and hypopnea, as well as percentage of time with oxygen saturation below 90\% [38]. However, there was a significant difference in BMI among groups $(27.58 \pm 3.28$ for OSAS versus $23.11 \pm 2.96 \mathrm{~kg} / \mathrm{m}^{2}$ for controls, $P<0.01$ ). Maeder et al. [55] found higher IL-6 serum levels after sleep in patients with moderate/severe OSAS when compared with mild or no OSAS patients $(P=0.005)$, but not before sleep $(P=0.08)$.

In a cross-sectional cohort study [33] enrolling 454 untreated OSAS patients, IL-6 serum levels were significantly correlated with ODI, hypoxia time, and minimum oxygen saturation in sleep. Nevertheless, after stratification by BMI, disease severity was associated with IL-6 levels only in obese individuals $\left(\mathrm{BMI}>30 \mathrm{~kg} / \mathrm{m}^{2}\right)$. Another group has included 23 healthy controls and 38 otherwise healthy OSAS patients and found no difference in serum IL-6 levels between the groups $(2.36 \pm 1.41$ versus $2.73 \pm 1.14 \mathrm{pg} / \mathrm{mL}, P=0.465)$ [23]

In a meta-analysis of 18 studies, IL- 6 plasma levels were increased among OSAS patients compared with controls (pooled mean difference 2.16) [30]. In a further meta-analysis of 8 studies [29] with a total of 165 patients, IL-6 level means ranged from 1.2 to $131.66 \mathrm{pg} / \mathrm{mL}$ before CPAP and from 0.45 to $66.04 \mathrm{pg} / \mathrm{mL}$ after CPAP. The pooled mean difference was 1.01 (95\% CI 0.00 to $2.03, P=0.05$ ) [29]. Among the works included in this meta-analysis, only 3 out of 8 showed attenuated IL- 6 serum levels after treatment, while there was no significant change in the remaining five [29]. Populations in these studies were small and exhibited comorbidities, like obesity.

Increased IL-6 levels are associated with OSAS severity and are often correlated with higher serum CRP levels, both cytokines being involved in the pathogenesis of cardiovascular and cerebrovascular disease.

\section{Cell Adhesion Molecules}

Adhesion of circulating leukocytes on the endothelial cells is considered as an important step in atherosclerosis initiation [56]. This process is enhanced by cellular adhesion molecules in response to proinflammatory cytokines, such as TNF- $\alpha$ and interleukin-1 [57]. Potential mediators in the leucocyte attachment to endothelium process include intercellular adhesion molecule-1 (ICAM-1), vascular cell adhesion molecule-1 (VCAM-1), and L-selectin [58]. The presence of these molecules is required for leucocyte migration in an inflamed area [59]. Previous reports have shown that hypoxia induces the expression of adhesion molecules in various cells, such as leukocytes and endothelial cells, also increasing neutrophil adherence to endothelium [60]. Although the role of cell adhesion molecules in OSAS has not yet been completely elucidated, there is evidence of elevation of circulating molecules [61-63].

In a study comparing 39 patients with moderate-tosevere OSAS with 34 nonapneic controls matched for age, gender, and BMI [64], circulating levels of both ICAM-1 and VCAM-1 were significantly higher in the OSAS group, as compared with the control group (480.1 \pm 216.7 versus $303.4 \pm 98.6 \mathrm{ng} / \mathrm{mL}, P<0.0001$, and $1156.6 \pm 79.8$ versus $878.8 \pm 71.1 \mathrm{ng} / \mathrm{mL}, P=0.002$, resp.). Additionally, a significant positive correlation of ICAM-1 levels and AHI was observed ( $r=0.276, P=0.018$ ) [64]. Multiple logistic regression analysis showed that the association between ICAM-1, VCAM-1 levels and OSAS was independent of age, gender, BMI, smoking status, and cardiovascular disease [64].

Ohga et al. [65] have found increased circulating levels of ICAM-1, VCAM-1, and L-selectin in OSAS patients before sleep, compared with a group of normal individuals matched for age, gender, and BMI (ICAM-1: $392.9 \pm 48.5$ versus 201.2 \pm $55 \mathrm{ng} / \mathrm{mL}, P<0.05$; VCAM-1: $811.0 \pm 87.8$ versus $574.2 \pm$ $42.7 \mathrm{ng} / \mathrm{mL}, P<0.05$; L-selectin: $1386.6 \pm 77.9$ versus $1038.8 \pm$ $78.6 \mathrm{ng} / \mathrm{mL}, P<0.01$, resp.). However, after sleep, only levels of L-selectin and ICAM-1 were significantly increased 
in OSAS subjects, suggesting that VCAM-1 levels might not be directly related to hypoxia-induced inflammation [65]. Similarly, in another report, increased levels of adhesion molecules were correlated with AHI and ODI but not with indices of hypoxemia severity and frequency of arousals [66].

A meta-analysis of 8 studies for ICAM, six studies for VCAM, and five studies for selectins has demonstrated higher serum levels of all molecules in OSAS patients compared with controls (pooled mean difference 2.93 for ICAM, 2.08 for VCAM, and 1.45 for selectins) [30]. Furthermore, a significant decrease in serum levels of cellular adhesion molecules was reported after one month of CPAP treatment [67]. Although the abovementioned reports illustrate the importance of these markers, they mostly include studies with a limited number of patients in which serum concentrations were measured by a single blood sample. Due to these limitations, it is conceivable that they may not accurately reflect their action at the level of vascular endothelium [68].

Taken together, results from various studies suggest that OSAS-induced hypoxia activates adhesion molecules. These inflammatory markers are associated with worse cardiovascular prognosis. Importantly, CPAP therapy could improve cardiovascular outcomes by a beneficial reduction of these markers.

\section{Fibrinogen}

Fibrinogen is an acute phase protein formed in the liver, and it may be elevated in various types of inflammation. Increased plasma levels of fibrinogen have been identified as a major independent risk factor for cardiovascular and cerebrovascular events [69]. Fibrinogen levels were increased in patients with coexisting OSAS and stroke, indicating a possible pathophysiological mechanism for the increased risk of stroke in such patients [70]. Hypoxia enhances fibrinogen production, and, indeed, morning levels of fibrinogen were found increased in OSAS patients compared with nonapneic controls $[71,72]$. The morning increase of fibrinogen concentration was attenuated after CPAP treatment [73].

The role of fibrinogen in OSAS has been widely studied $[74,75]$. In a recent investigation by Shamsuzzaman et al. [76], plasma fibrinogen levels were increased in patients with severe OSAS compared with mild OSAS patients and controls matched for age, BMI, smoking habits, and hemodynamics ( $398 \pm 18$ versus $331 \pm 25, P=0.003$ and $398 \pm 18$ versus $334 \pm$ $25 \mathrm{mg} / \mathrm{dL}, P=0.02$, resp.). However, no significant difference was noted in fibrinogen levels between mild OSAS group and controls, suggesting that the partial sleep loss due to arousals and the level of hypoxia during sleep may represent the main regulators of fibrinogen levels [76]. Serum fibrinogen levels were directly related to AHI and arousal index and inversely related to mean and lowest oxyhemoglobin saturation during sleep [76].

An analysis of 10 studies on hemostatic variables in OSAS has demonstrated that the average minimal oxygen saturation was an independent predictor of fibrinogen [77]. However, a number of authors failed to demonstrate an association between plasma fibrinogen levels and OSAS $[23,78]$. In a study including 30 children with snoring and OSAS, 61 children with snoring and no OSAS, and 23 controls, fibrinogen levels were higher in the OSAS group compared with both non-OSAS snorers and control groups (318 versus 307 and $271 \mathrm{mg} / \mathrm{dL}$, resp., $P<0.05$ ) [78]. Factors influencing serum fibrinogen levels commonly coexisting in OSAS include obesity, age, tobacco smoking, and alcohol consumption $[74,79]$.

In summary, serum fibrinogen levels are increased in OSAS patients and are associated with disease severity, indicating increased risk for thrombosis.

\section{Markers of Oxidative Stress}

Oxidative stress is characterized by an imbalance between oxidant mechanisms, such as reactive oxygen species, and the antioxidant system that includes various enzymatic and nonenzymatic processes. Reactive oxygen species react with DNA, lipids, and proteins, leading to cell injury, endothelial damage, and vasoconstriction, thereby increasing the risk of atherosclerosis [80]. The presence of systemic oxidative stress is considered as an important mechanism linking OSAS with cardiovascular disease and metabolic perturbations [81]. Repetitive episodes of upper airway collapse followed by adequate ventilation cause multiple periods of hypoxia and reoxygenation. These repeated events are considered to play a role analogous to hypoxia-reperfusion injury, which enhances oxidative stress [82].

Previous data have indicated increased oxidative stress in OSAS patients along with decreased antioxidant capacity compared with healthy controls [83]. Conversely, several reports failed to demonstrate such an association, possibly due to confounding factors $[84,85]$. Lee et al. [84] have compared serum total antioxidant status between a group of 31 mild-to-moderate OSAS patients, a group of 22 severe OSAS patients, and 20 controls matched for age, BMI, but not smoking habits. Total antioxidant status was similar among groups considered $(1.87 \pm 0.3$ for mild/moderate OSAS, $1.94 \pm$ 0.32 for severe OSAS, and $1.96 \pm 0.32 \mathrm{mmol} / \mathrm{L}$ for controls, resp., $P=0.53$ ).

Isoprostanes are a class of prostanoids formed by free radical-catalyzed peroxidation of essential fatty acids, primarily arachidonic acids [86]. In the study of Tan et al. [87], plasma 8-isoprostane levels were elevated in a group of 128 OSAS patients compared with 82 controls (125.8 [94.9-256.2] versus 120.6 [86.4-166.3] pg/mL resp., $P<0.01)$. However, OSAS patients were older and exhibited higher BMI than controls [87]. Relevant conclusions were reached by Barceló et al. [88], who compared serum 8-isoprostane levels of 119 OSAS patients and an equal number of controls matched for sex, age, and BMI (11.4 versus $4.3 \mathrm{U} / \mathrm{L}$, resp., $P=0.001$ ). In a randomized crossover study by Fernández et al. [89] assessing the effect of CPAP therapy on oxidative stress, plasma 8-isoprostane levels were significantly decreased after 12 weeks of treatment (38.5 [24.2-58.7] at baseline versus 22.5 [16.2-35.3] pg/mL after treatment, $P=0.0001$ ) in 31 newly diagnosed OSAS patients without comorbidities.

However, another group has measured serum 8isoprostane levels in 41 moderate-severe OSAS patients and 35 matched controls before sleep, after 4 hours of untreated 
OSA and after 4 hours of effective treatment with CPAP [90]. 8-isoprostane levels in OSAS patients were comparable to those of control individuals and remained unaffected by CPAP treatment and normal sleep period [90].

Malondialdehyde (MDA) is a product of lipid peroxidation, which may have implications in the development of cardiovascular disease [91]. Higher MDA levels are considered an index of increased stress-induced lipid peroxidation [92]. Several reports used MDA plasma levels as a parameter of oxidative stress in OSAS patients [93,94]. Jurado-Gámez et al. [95] have included 46 OSAS patients and matched for age, sex, and BMI 23 non-OSAS subjects. They have found that MDA serum levels were increased among the former $(P=$ 0.001) [95]. In the same work, serum levels were attenuated after 3 months of CPAP treatment (3.2 before and $1.9 \mu \mathrm{M}$ after CPAP therapy, $P=0.001)$. Similar findings were reported in another study [96]. In another study, MDA concentrations correlated with the duration of nocturnal desaturation below 85\% ( $r=0.77, P<0.0005)$ [97]. At the same time, serum MDA levels were progressively increased during the night and they reached their maximum concentration one hour after awakening [97]. These observations are consistent with the hypothesis that intermittent hypoxia induces oxidative stress in OSAS patients.

Total levels of antioxidant enzymes, as well as total antioxidant status (TAS), have been studied in OSAS patients. Cofta et al. [98] have found that TAS serum concentration was progressively decreased in comparison with matched control subjects and OSAS patients of increasing severity (1.58 for controls, 1.34 for AHI 5-15, 1.46 for AHI 16-30, and $1.38 \mathrm{mmol} / \mathrm{L}$ for $\mathrm{AHI} \geq 30, P=0.03$ ). Similar results were reported by other authors [99]. TAS values were found lower immediately after sleep, compared with those before sleep, in individuals with less severe OSAS but not in those with severe syndrome $(1.73 \pm 0.08$ versus $1.65 \pm 0.09 \mathrm{mmol} / \mathrm{L}, P=0.01$; and $1.64 \pm 0.12$ versus $1.58 \pm 0.10 \mathrm{mmol} / \mathrm{L}, P=0.07$, resp.) [83]. These results may reflect the difference of the acute effect of hypoxemia induced by apneic sleep and a chronic state of oxidative stress that may exist in severe syndrome even during daytime. TAS levels were negatively correlated with arousals $(r=-0.29, P=0.04)$ [100].

However, a recent study failed to demonstrate the abovementioned relationships [101]. Total antioxidant capacity was measured in 18 patients with severe OSAS and 13 control subjects before and the morning after PSG [101]. Results showed no difference in total antioxidant capacity between groups $(0.92 \pm 0.16$ versus $0.98 \pm 0.19 \mathrm{~m} \mathrm{MDPPH}$, resp., $P=$ $0.41)$.

Paraoxonase $(\mathrm{PON})$ is an antioxidant enzyme protecting low-density lipoprotein from oxidation [102]. Lavie et al. [103] have reported higher serum levels of lipid peroxidation products and lower PON-1 levels in OSAS patients with and without cardiovascular disease compared with controls $(79.5 \pm 13.6$ versus $86.7 \pm 17.6$ versus $92.1 \pm 14.4 \mathrm{U} \cdot \mathrm{min} / \mathrm{mL}$, resp., $P=0.002)$. They have also observed a negative correlation between PON-1 activity and RDI $(r=-0.24$, $P<0.01)$ [103]. Other works have also confirmed decreased plasma levels of PON in OSAS compared with controls [99, 104].
In another study, PON-1 activity was lower in OSAS patients and in COPD patients compared with controls, suggesting that both nocturnal intermittent and sustained hypoxemia may have an effect on diminished PON-1 concentration [105]. CPAP treatment has proven to increase levels of PON-1 in OSAS patients $(104.0 \pm 10.5$ before treatment versus $120.3 \pm 8.6 \mathrm{U} / \mathrm{L}$ after treatment) [106]. By contrast, Vatansever et al. [94] showed no significant difference in PON activity between OSAS patients and controls. The authors suggested that PON activity alterations probably depend on the presence of cardiovascular disease in OSAS [94].

In conclusion, OSAS is associated with increased oxidative stress. Putative underlying mechanisms include increased production of oxidant factors or decreased antioxidant capacity, both due to hypoxia induced by apneic events. Further studies with adequately selected patients are needed to clarify the role of OSAS in inducing an oxidative state.

\section{Metabolic Markers}

Evidence suggests that intermittent hypoxia and oxyhemoglobin desaturation, both hallmarks of OSAS, may induce impaired glucose and lipid metabolism, as well as insulin resistance and metabolic syndrome [107, 108]. Hemoglobin Alc $\left(\mathrm{HbA}_{1 \mathrm{c}}\right)$ has been found elevated in nondiabetic OSAS patients and was negatively correlated with minimum oxyhemoglobin desaturation levels $(r=-0.302, P=0.018)$ and positively correlated with mean desaturation index $(r=$ $0.263, P=0.041$ ) [109]. In a cross-sectional observational study on obese patients, a significant U-shaped association $\left(R^{2}=0.241, P<0.0005\right)$ between sleep duration and $\mathrm{HbA}_{1 \mathrm{c}}$ was found [110]. Decreased duration of slow-wave sleep (N3) was associated with decreased insulin secretion [110]. The relationship between OSAS and $\mathrm{HbA}_{1 \mathrm{c}}$ has been extensively investigated [111, 112].

Priou et al. [113] investigated the association between OSAS severity and $\mathrm{HbA}_{1 \mathrm{c}}$ in 1599 patients without diabetes. A positive association between $\mathrm{HbA}_{1 \mathrm{c}}$ and severity of OSAS was observed $(5.6 \pm 0.3 \%$ for $\mathrm{AHI}<5,5.6 \pm 0.3 \%$ for $5 \leq \mathrm{AHI}$ $\leq 15,5.7 \pm 0.3 \%$ for $15 \leq \mathrm{AHI} \leq 30,5.7 \pm 0.4 \%$ for $30 \leq \mathrm{AHI} \leq$ 50 , and $5.8 \pm 0.3 \%$ for AHI $\geq 50, P<0.0001)$. Additionally, a dose-response relationship was demonstrated between AHI and percentage of patients with $\mathrm{HbA}_{1 \mathrm{c}}>6.0 \%$ ranging from $10.8 \%$ for $\mathrm{AHI}<5$ to $34.2 \%$ for $\mathrm{AHI} \geq 50$, suggesting an increased risk for developing diabetes among these patients. In nondiabetic subjects, $\mathrm{HbA}_{1 \mathrm{c}}$ was positively correlated with arousal index $(\beta=0.448, P=0.014)$ and percentage of sleep time with oxyhemoglobin saturation below $90 \%$ ( $\beta=$ $0.470, P=0.01)$ and negatively with average oxyhemoglobin saturation $(\beta=-0.456, P=0.012)[114]$.

The effect of CPAP therapy on glycemic control has been the subject of many investigations, often leading to conflicting results $[115,116]$. Results from two meta-analyses showed no significant influence of CPAP treatment on $\mathrm{HbA}_{1 \mathrm{c}}$, while another meta-analysis showed an improvement of insulin resistance in nondiabetic OSAS subjects [117-119]. Further studies are needed in order to evaluate the effects of long time therapy of OSAS on glycemic control. 
Leptin is secreted by adipocytes in proportion to fat mass, and it suppresses appetite [120]. Leptin levels have been evaluated in OSAS patients [62, 121]. Increased leptin levels have been found in patients with severe OSAS compared with controls $(9.05 \pm 5.91$ versus $4.24 \pm 1.78 \mathrm{ng} / \mathrm{mL}, P<0.01)$ [122]. Serum leptin levels were positively correlated with AHI $(r=0.552, P<0.001)$ and oxyhemoglobin saturation below 90\% $(r=0.399, P<0.001)$, as well as BMI $(r=0.807$, $P<0.0001)$, demonstrating an increase of leptin levels with increasing OSAS severity [122]. However, there was a significant difference in BMI between OSAS patients and controls, which may be relevant [122].

By contrast, several authors have failed to demonstrate an association between leptin levels and OSAS [123, 124]. A study comparing leptin levels between obese and nonobese OSAS patients and obese and nonobese controls found no differences in serum concentrations between these groups (19.27 for obese OSAS versus $16.06 \mathrm{ng} / \mathrm{mL}$ for obese controls, $P=0.848$; and 7.02 for nonobese OSAS versus $7.85 \mathrm{ng} / \mathrm{mL}$ for nonobese controls, $P=0.393$ ). Leptin levels differed significantly between obese and nonobese OSAS patients (19.27 versus $7.02 \mathrm{ng} / \mathrm{mL}, P<0.001)$ and obese and nonobese controls (16.06 versus $7.85 \mathrm{ng} / \mathrm{mL}, P=0.004$ ). After 3 months of CPAP treatment, leptin levels were significantly decreased only in obese OSAS patients (19.27 before and $15.48 \mathrm{ng} / \mathrm{mL}$ after treatment, respectively, $P=0.016$ ) [124].

Adiponectin is secreted by adipose tissue and is inversely related to the percentage of body fat, also exhibiting a negative correlation with insulin resistance [125]. Its plasma levels in OSAS patients were negatively correlated with sympathetic activation, expressed as urinary secretion of norepinephrine and normetanephrine $(r=-0.231, P<$ $0.008)$, possibly resulting from sleep-disordered breathing [126]. Additional evidence suggests that hypoxic stress may reduce serum adiponectin in OSAS patients by acting at transcriptional and posttranscriptional levels [127]. Zhang et al. [128] found significantly lower adiponectin levels in OSAS patients compared with simple snorers $(4.56 \pm 2.12$ versus $7.66 \pm 3.71 \mu \mathrm{g} / \mathrm{mL}$, resp., $P<0.01)$. Of note, this difference was more pronounced in the group of moderate and severe syndrome, thus suggesting an independent effect of disease severity on adiponectin serum levels [128]. Serum adiponectin levels were also negatively correlated with AHI $(r=-0.361, P<0.01)$, but positively correlated with nadir oxyhemoglobin saturation $(r=0.306, P<0.05)$ [128].

In another study [37], plasma adiponectin levels were negatively correlated with time spent in oxyhemoglobin saturation below 90\% $(r=-0.229, P=0.007)$ and positively with minimum oxygen saturation $(r=0.250, P=$ 0.003 ). However, the robust relationship of adiponectin levels with body fat and the presence of obesity has led various studies to conflicting results, with some demonstrating an association between OSAS and low adiponectin levels and others emphasizing the role of obesity as an important confounding factor $[94,122,129]$. Tokuda et al. [122] have compared serum adiponectin levels between 21 moderate OSAS patients, 32 severe OSAS patients, and 15 controls. There was no difference in serum adiponectin levels among the groups $(4.28 \pm 1.92$ for moderate OSAS versus $4.58 \pm 2.47$ for severe OSAS versus $4.61 \pm 1.81 \mu \mathrm{g} / \mathrm{mL}$ for controls). Serum adiponectin levels were the determinant factor for $\% \mathrm{~T}<90$. Similar controversy also exists regarding the effects of CPAP therapy [28, 123, 130-132].

Resistin is an adipocytokine implicated in the development of obesity, insulin resistance, and metabolic syndrome $[133,134]$. In a study comparing 31 OSAS patients with 10 matched controls, higher resistin plasma levels were found in OSAS (22.0 versus $15.8 \mathrm{ng} / \mathrm{mL}$, resp., $P<0.05)$ with an increasing trend with progressing disease severity $(P<0.05)$ [135]. The average oxyhemoglobin saturation during sleep was the principal determinant of resistin levels $(P<0.01)$, while CPAP therapy decreased serum levels to baseline [135]. Conversely, other groups have shown weak or no correlation between OSAS and resistin levels, indicating body weight as the dominant modulator of insulin resistance $[123,136]$. In a study including 20 obese OSAS patients, 6 months of CPAP treatment did not affect resistin serum levels $(3.1 \pm 0.4$ before treatment versus $3.2 \pm 0.4 \mathrm{ng} / \mathrm{mL}$ after treatment, $P=0.79$ ) [123].

Diabetes mellitus represents a frequent comorbidity among OSAS patients and may further increase the risk of cardiovascular complications [137]. Even though studies investigating the effects of CPAP treatment on glycemic control brought conflicting results, the evaluation of serum biomarkers may help to distinguish a group of OSAS patients that may benefit from some therapeutic intervention.

\section{New Biomarkers}

Ongoing research has seen the identification of novel biomarkers of OSAS. Additional studies on a larger scale are necessary to investigate the utility of these markers in OSAS including treatment effect. Matrix metalloproteinases (MMPs) are endoproteases that cleave extracellular matrix and play an important role in cardiac and vascular remodeling [138]. Production of MMPs is stimulated by hypoxia and by various cytokines [139]. Monocytes isolated from OSAS patients appear to produce more MMP-9 than those from controls $[139,140]$. Variability in serum level of MMPs among OSAS patients is also under investigation [140].

Tazaki et al. [141] have measured serum levels and enzymatic activity of MMP-9 in OSAS patients and a group of matched controls. A significant increase was observed among the former $(91.9 \pm 9.8$ for controls versus $120.3 \pm$ 7.8 for mild OSAS, $P<0.05$, and $168.0 \pm 18.9 \mathrm{ng} / \mathrm{mL}$ for moderate to severe OSAS, $P<0.01)$. Enzymatic activity was also increased in OSAS patients [141]. OSAS severity emerged as the primary factor influencing MMP-9 levels and activity, while one month of CPAP treatment significantly decreased both parameters [141]. Impressively, in OSAS patients sustaining uvulopalatal flap surgery, postoperative serum concentrations of MMP-9 were significantly lower in comparison to preoperative values [142].

Thioredoxin (TRX) is a protein playing a protective role against oxidant injury [143]. In animal models, increased tissue TRX activity may be identified as a response to chronic intermittent hypoxia [144]. TRX was also highly expressed in OSAS tonsils at the mRNA and protein levels [145]. Serum 
TABLE 1: Studies assessing inflammatory biomarkers in obstructive sleep apnea syndrome.

\begin{tabular}{|c|c|c|c|}
\hline Study & Biomarkers & Comparison groups & Comments \\
\hline Sahlman et al. [20] & $\begin{array}{l}\text { CRP } \\
\text { TNF- } \alpha \\
\text { IL-6 }\end{array}$ & $\begin{array}{l}84 \text { mild OSAS patients versus } 40 \\
\text { non-OSAS controls }\end{array}$ & $\begin{array}{l}\text { CRP and TNF- } \alpha \text {, but not IL- } 6 \text {, levels were higher in the } \\
\text { OSAS group. CRP levels increased with the increase of } \\
\text { AHI }\end{array}$ \\
\hline Shamsuzzaman et al. [21] & CRP & $\begin{array}{l}22 \text { OSAS patients versus } 20 \\
\text { non-OSAS controls }\end{array}$ & $\begin{array}{l}\text { CRP levels were higher in OSAS group and were } \\
\text { independently associated with OSAS severity }\end{array}$ \\
\hline Hayashi et al. [22] & CRP & $\begin{array}{l}60 \text { OSAS patients versus } 30 \\
\text { non-OSAS controls }\end{array}$ & $\begin{array}{l}\text { CRP levels were higher in the OSAS group and } \\
\text { increased with OSAS severity. Repetitive hypoxaemia } \\
\text { correlated with CRP levels }\end{array}$ \\
\hline Steiropoulos et al. [23] & $\begin{array}{l}\text { CRP } \\
\text { TNF- } \alpha \\
\text { IL-6 } \\
\text { Fibrinogen }\end{array}$ & $\begin{array}{l}38 \text { OSAS patients versus } 23 \\
\text { non-OSAS controls }\end{array}$ & $\begin{array}{l}\text { TNF- } \alpha \text { levels were higher in OSAS patients and were } \\
\text { correlated with neck circumference, AHI, and ODI. } \\
\text { No differences in CRP, IL-6, and fibrinogen levels were } \\
\text { recorded between groups }\end{array}$ \\
\hline Guven et al. [24] & CRP & $\begin{array}{l}47 \text { OSAS patients versus } 29 \\
\text { non-OSAS controls }\end{array}$ & $\begin{array}{l}\text { CRP levels were higher in the OSAS group and were } \\
\text { positively correlated with BMI and AHI }\end{array}$ \\
\hline Hall et al. [25] & CRP & $\begin{array}{l}161 \text { OSAS patients versus } 61 \\
\text { controls }\end{array}$ & $\begin{array}{l}\text { CRP levels were higher in the OSAS group and were } \\
\text { associated with AHI }\end{array}$ \\
\hline Yokoe et al. [26] & $\begin{array}{l}\text { CRP } \\
\text { IL-6 }\end{array}$ & $\begin{array}{l}30 \text { OSAS patients versus } 14 \\
\text { non-OSAS obese controls }\end{array}$ & $\begin{array}{l}\text { CRP and IL- } 6 \text { levels were higher in patients with OSAS. } \\
\text { CRP levels were influenced by severity of OSAS and } \\
\text { BMI. IL-6 levels were influenced by nocturnal hypoxia } \\
\text { and BMI }\end{array}$ \\
\hline Guilleminault et al. [31] & CRP & $\begin{array}{l}146 \text { OSAS patients versus } 39 \\
\text { UARS patients versus } 54 \\
\text { non-OSAS controls }\end{array}$ & $\begin{array}{l}\text { CRP levels did not differ among groups. BMI was } \\
\text { associated with increased CRP values }\end{array}$ \\
\hline Ryan et al. [32] & CRP & $\begin{array}{l}35 \text { mild-to-moderate OSAS } \\
\text { patients versus } 31 \text { severe OSAS } \\
\text { patients versus } 14 \text { obese severe } \\
\text { OSAS patients versus } 30 \\
\text { non-OSAS controls }\end{array}$ & $\begin{array}{l}\text { CRP levels were higher in the obese severe OSAS group } \\
\text { than in the other groups. BMI was an independent } \\
\text { predictor for CRP levels }\end{array}$ \\
\hline Vgontzas et al. [35] & $\begin{array}{l}\text { TNF- } \alpha \\
\text { IL-6 }\end{array}$ & $\begin{array}{l}14 \text { OSAS patients versus } 11 \text { obese } \\
\text { non-OSAS controls versus } 12 \\
\text { normal weight controls }\end{array}$ & $\begin{array}{l}\text { TNF- } \alpha \text { and IL- } 6 \text { values were highest in the OSAS group } \\
\text { and lowest in the lean controls. Their values for obese } \\
\text { controls were between those of the other groups }\end{array}$ \\
\hline Minoguchi et al. [36] & TNF- $\alpha$ & $\begin{array}{l}24 \text { mild and moderate-to-severe } \\
\text { OSAS patients versus } 15 \text { obese } \\
\text { non-OSAS controls versus } 12 \\
\text { healthy subjects }\end{array}$ & $\begin{array}{l}\text { TNF- } \alpha \text { levels were higher in patients with } \\
\text { moderate-to-severe OSAS than in patients with mild } \\
\text { OSAS, obese control subjects, or healthy subjects. The } \\
\text { duration of hypoxia was independently associated with } \\
\text { production of TNF- } \alpha \text { by monocytes }\end{array}$ \\
\hline Kanbay et al. [37] & TNF- $\alpha$ & $\begin{array}{l}106 \text { OSAS patients versus } 32 \\
\text { non-OSAS controls }\end{array}$ & $\begin{array}{l}\text { TNF- } \alpha \text { levels were increased in OSAS group, positively } \\
\text { correlated with } \mathrm{SaO}_{2}<90 \% \text { and BMI and negatively } \\
\text { with adiponectin levels }\end{array}$ \\
\hline Liu et al. [38] & $\begin{array}{l}\text { TNF- } \alpha \\
\text { IL-6 }\end{array}$ & $\begin{array}{l}22 \text { OSAS patients versus } 16 \\
\text { non-OSAS controls }\end{array}$ & $\begin{array}{l}\text { TNF- } \alpha \text { and IL- } 6 \text { levels were higher in OSAS group and } \\
\text { were correlated with percentage of time of apneas and } \\
\text { hypopneas and with percentage of time spending at } \\
\mathrm{SaO}_{2}<90 \%\end{array}$ \\
\hline Ciftci et al. [39] & $\begin{array}{l}\text { TNF- } \alpha \\
\text { IL-6 }\end{array}$ & $\begin{array}{l}43 \text { obese OSAS patients versus } 22 \\
\text { BMI matched non-OSAS } \\
\text { controls }\end{array}$ & $\begin{array}{l}\text { TNF- } \alpha \text { and IL- } 6 \text { levels were higher in OSAS group and } \\
\text { were correlated with AHI but not with BMI }\end{array}$ \\
\hline Ciccone et al. [40] & $\begin{array}{l}\text { CRP } \\
\text { TNF- } \alpha \\
\text { IL-6 }\end{array}$ & $\begin{array}{l}26 \text { mild OSAS versus } 54 \\
\text { moderate-to-severe OSAS versus } \\
40 \text { controls }\end{array}$ & $\begin{array}{l}\text { CRP, TNF- } \alpha \text {, and IL- } 6 \text { levels were higher in } \\
\text { moderate/severe OSAS than in other groups }\end{array}$ \\
\hline Imagawa et al. [43] & $\begin{array}{l}\text { TNF- } \alpha \\
\text { IL-6 }\end{array}$ & $\begin{array}{l}110 \text { severe OSAS patients versus } \\
45 \text { non-OSAS controls }\end{array}$ & $\begin{array}{l}\text { TNF- } \alpha \text { and IL- } 6 \text { levels did not differ between groups. } \\
\text { BMI was correlated with the severity of the AHI }\end{array}$ \\
\hline Guasti et al. [44] & $\begin{array}{l}\text { TNF- } \alpha \\
\text { IL-8 }\end{array}$ & $\begin{array}{l}16 \text { OSAS patients versus } 11 \\
\text { non-OSAS controls }\end{array}$ & $\begin{array}{l}\text { Resting and stimulated TNF- } \alpha \text { and IL- } 8 \text { release, as well } \\
\text { as serum levels, were similar in the two groups }\end{array}$ \\
\hline
\end{tabular}


TABLE 1: Continued.

\begin{tabular}{|c|c|c|c|}
\hline Study & Biomarkers & Comparison groups & Comments \\
\hline Ohga et al. [48] & $\begin{array}{l}\text { IL-8 } \\
\text { ICAM-1 }\end{array}$ & $\begin{array}{l}20 \text { OSAS patients versus } 10 \\
\text { non-OSAS controls }\end{array}$ & $\begin{array}{l}\text { IL- } 8 \text { and ICAM-1 levels were higher in OSAS patients } \\
\text { and were correlated with apnea index and desaturation } \\
\text { magnitude }\end{array}$ \\
\hline Alzoghaibi [50] & IL-8 & $\begin{array}{l}25 \text { severe OSAS patients versus } 17 \\
\text { non-OSAS controls }\end{array}$ & IL-8 levels were higher in OSAS group \\
\hline Cofta et al. [61] & $\begin{array}{c}\text { CRP } \\
\text { E-selectin } \\
\text { L-selectin } \\
\text { P-selectin }\end{array}$ & $\begin{array}{l}60 \text { OSAS patients versus } 20 \\
\text { non-OSAS controls }\end{array}$ & $\begin{array}{l}\text { CRP and selectins levels progressively increased with } \\
\text { increasing severity of OSAS }\end{array}$ \\
\hline Testelmans et al. [62] & $\begin{array}{c}\text { CRP } \\
\text { TNF- } \alpha \\
\text { IL-8 } \\
\text { IL-6 } \\
\text { ICAM-1 }\end{array}$ & $\begin{array}{l}15 \text { non-OSAS controls versus } 12 \\
\text { patients with cardiovascular } \\
\text { disease versus } 15 \text { OSAS patients } \\
\text { with cardiovascular disease } \\
\text { versus } 15 \text { non-obese OSAS } \\
\text { patients versus } 15 \text { obese OSAS } \\
\text { patients }\end{array}$ & $\begin{array}{l}\text { CRP, TNF- } \alpha \text {, IL- } 8 \text {, IL- } 6 \text {, and ICAM-1 levels were higher } \\
\text { in patients with acute cardiovascular events and OSAS } \\
\text { and were associated with AHI }\end{array}$ \\
\hline Ursavas et al. [64] & $\begin{array}{l}\text { ICAM-1 } \\
\text { VCAM-1 }\end{array}$ & $\begin{array}{l}39 \text { moderate-to-severe OSAS } \\
\text { patients versus } 34 \text { non-OSAS } \\
\text { controls }\end{array}$ & $\begin{array}{l}\text { ICAM-1 and VCAM-1 levels were increased in the } \\
\text { OSAS group. ICAM-1 levels were correlated with AHI }\end{array}$ \\
\hline Ohga et al. [65] & $\begin{array}{l}\text { ICAM-1 } \\
\text { VCAM-1 } \\
\text { L-selectin }\end{array}$ & $\begin{array}{l}7 \text { OSAS patients versus } 6 \\
\text { non-OSAS controls }\end{array}$ & $\begin{array}{l}\text { ICAM-1, VCAM-1, and L-selectin levels were increased } \\
\text { in OSAS group before sleep compared with controls. } \\
\text { Only ICAM-1 and L-selectin levels were increased after } \\
\text { sleep }\end{array}$ \\
\hline Basoglu et al. [74] & $\begin{array}{c}\text { CRP } \\
\text { Fibrinogen } \\
\end{array}$ & $\begin{array}{l}36 \text { obese OSAS patients versus } 34 \\
\text { obese non-OSAS controls }\end{array}$ & $\begin{array}{l}\text { CRP and fibrinogen levels were higher in obese OSAS } \\
\text { patients }\end{array}$ \\
\hline Shamsuzzaman et al. [76] & Fibrinogen & $\begin{array}{l}10 \text { mild OSAS patients versus } 26 \\
\text { severe OSAS patients versus } 18 \\
\text { non-OSAS controls }\end{array}$ & $\begin{array}{l}\text { Fibrinogen levels were elevated in patients with severe } \\
\text { OSAS compared with other groups }\end{array}$ \\
\hline
\end{tabular}

TRX levels were increased in OSAS patients in comparison with healthy controls and were decreased after CPAP therapy [146]. Guo et al. [147] have found that TRX plasma levels were positively correlated to AHI $(r=0.313, P<0.05)$ and negatively to the lowest oxygen saturation $(r=-0.266$, $P=0.037$ ). A cut-off value of $9.39 \mathrm{ng} / \mathrm{mL}$ could identify OSAS patients (sensitivity $91 \%$, specificity $78 \%$ ), while the cut-off value that differentiated mild from moderate-severe syndrome was $11.79 \mathrm{ng} / \mathrm{mL}$ (sensitivity $75 \%$, specificity $65 \%$ ), suggesting a potential role for TRX levels as a measure of OSAS severity [147].

Cysteine is derived from homocysteine through a transsulfuration pathway and its increased plasma levels have been associated with cardiovascular risk [148]. Serum cysteine levels have already been found significantly higher in OSAS patients compared with non-OSAS controls (490.16 \pm 67 versus $439.81 \pm 76.12 \mathrm{mmol} / \mathrm{L}$, resp., $P<0.01)$ and this difference was maintained after inclusion of nonobese patients [149]. Six-month CPAP treatment significantly decreased cysteine levels [149].

Finally, hepcidin is produced by the liver and its levels are increased in inflammation, mainly as a response to elevated IL-6 levels. Given the systemic inflammatory state and the increase of IL-6 in OSAS, hepcidin might emerge as a new biomarker in OSAS [150].

\section{Concluding Comments}

A large body of evidence points to an increased risk of cardiovascular disease, insulin resistance, and metabolic syndrome in OSAS [151]. As with any disease process, timely diagnosis and therapy may not only improve outcomes, but also reduce the likelihood of future complications. Even though studies have focused on various biomarkers that could facilitate OSAS diagnosis and management, an ideal marker has yet to be discovered (Table 1).

The pathogenesis of OSAS complications is multifactorial, including systemic inflammation, oxidative stress, and metabolic perturbations. A biomarker sensitive enough to specific aspects of OSAS may permit the design of interventions intended to modulate pathogenic pathways. The essence of treatment is maintaining airway patency during sleep through CPAP, oral appliances, surgery, and weight loss. Although considerable progress has been made, results are not always certain and long term follow-up is usually required (Table 2). Thus, the utility of new biomarkers might be important.

Use of overnight PSG for patient follow-up is the gold standard, but it may be criticized for being time consuming, not always widely available and for increasing cost. Therefore, biomarkers to evaluate treatment effect are highly desirable, 
TABLE 2: Effects of continuous positive airway pressure treatment on several biomarkers in obstructive sleep apnea syndrome.

\begin{tabular}{|c|c|c|c|}
\hline Study & Biomarkers & $\begin{array}{l}\text { CPAP treatment } \\
\text { duration }\end{array}$ & Comments \\
\hline Yokoe et al. [26] & $\begin{array}{l}\text { CRP } \\
\text { IL-6 }\end{array}$ & 1 month & $\begin{array}{l}\text { CRP, IL-6 levels, and spontaneous IL- } 6 \text { production by monocytes } \\
\text { were significantly decreased after treatment }\end{array}$ \\
\hline Steiropoulos et al. [27] & CRP & 6 months & $\begin{array}{l}\text { CRP levels were decreased in the group with good adherence to } \\
\text { treatment }\end{array}$ \\
\hline Kohler et al. [28] & $\begin{array}{l}\text { CRP } \\
\text { IL-6 }\end{array}$ & 1 month & CRP and IL-6 levels were not decreased after treatment \\
\hline Minoguchi et al. [36] & TNF- $\alpha$ & 1 month & $\begin{array}{l}\text { Serum levels and spontaneous production of TNF- } \alpha \text { were decreased } \\
\text { in patients with moderate-to-severe OSAS }\end{array}$ \\
\hline Steiropoulos et al. [41] & $\begin{array}{l}\text { TNF- } \alpha \\
\text { IL-6 }\end{array}$ & 6 months & $\begin{array}{l}\text { TNF- } \alpha \text { levels were decreased in the good compliance group after } \\
\text { treatment. IL- } 6 \text { levels did not alter with treatment }\end{array}$ \\
\hline Hegglin et al. [42] & TNF- $\alpha$ & 8 months & $\begin{array}{l}\text { TNF- } \alpha \text { levels were decreased in men independently from compliance } \\
\text { to CPAP use, but not in women }\end{array}$ \\
\hline Guasti et al [44] & $\begin{array}{l}\text { TNF- } \alpha \\
\text { IL-8 }\end{array}$ & 12 weeks & TNF- $\alpha$ and IL- 8 levels remained unchanged after treatment \\
\hline Ohga et al. [48] & $\begin{array}{c}\text { IL-8 } \\
\text { ICAM-1 }\end{array}$ & $8-18$ months & IL-8 and ICAM-1 levels were decreased after treatment \\
\hline Oyama et al. [49] & $\begin{array}{l}\text { TNF- } \alpha \\
\text { IL-8 } \\
\text { IL-6 }\end{array}$ & 3 months & TNF- $\alpha$, IL- 8 , and IL- 6 levels were decreased after treatment \\
\hline Chin et al. [67] & $\begin{array}{l}\text { VCAM-1 } \\
\text { ICAM-1 } \\
\text { E-selectin }\end{array}$ & $\begin{array}{l}3-4 \text { days, } \\
1 \text { month, } \\
6 \text { months }\end{array}$ & $\begin{array}{l}\text { After } 1 \text { month E-selectin and ICAM-1 levels but not VCAM-1 had } \\
\text { decreased. } \\
\text { After } 6 \text { months VCAM-1 levels did not change, while ICAM-1 levels } \\
\text { further decreased }\end{array}$ \\
\hline
\end{tabular}

given that they may contribute to reduced waiting time in sleep laboratories and insurance costs. Finally, sophisticated molecular techniques may help identify the ideal biomarker of the future [152]. For the time being, however, caution is needed in the interpretation of available results.

\section{Conflict of Interests}

The authors declare that there is no conflict of interests regarding the publication of this paper.

\section{References}

[1] American Academy of Sleep Medicine, "Sleep-related breathing disorders in adults: recommendations for syndrome definition and measurement techniques in clinical research. The report of an American Academy of Sleep Medicine task force," Sleep, vol. 22, no. 5, pp. 667-689, 1999.

[2] T. Young, M. Palta, J. Dempsey, J. Skatrud, S. Weber, and S. Badr, "The occurrence of sleep-disordered breathing among middleaged adults," The New England Journal of Medicine, vol. 328, no. 17, pp. 1230-1235, 1993.

[3] Y. Peker, J. Hedner, J. Norum, H. Kraiczi, and J. Carlson, "Increased incidence of cardiovascular disease in middle-aged men with obstructive sleep apnea: a 7-year follow-up," The American Journal of Respiratory and Critical Care Medicine, vol. 166, no. 2, pp. 159-165, 2002.

[4] C. L. Bassetti, M. Milanova, and M. Gugger, "Sleep-disordered breathing and acute ischemic stroke: diagnosis, risk factors, treatment, evolution, and long-term clinical outcome," Stroke, vol. 37, no. 4, pp. 967-972, 2006.
[5] A. S. M. Shamsuzzaman, B. J. Gersh, and V. K. Somers, "Obstructive sleep apnea: implications for cardiac and vascular disease," Journal of the American Medical Association, vol. 290, no. 14, pp. 1906-1914, 2003.

[6] I. Eisensehr, B. L. Ehrenberg, S. Noachtar et al., "Platelet activation, epinephrine, and blood pressure in obstructive sleep apnea syndrome," Neurology, vol. 51, no. 1, pp. 188-195, 1998.

[7] P. Stiefel, M. A. Sánchez-Armengol, J. Villar, A. Vallejo-Vaz, R. Moreno-Luna, and F. Capote, "Obstructive sleep apnea syndrome, vascular pathology, endothelial function and endothelial cells and circulating microparticles," Archives of Medical Research, vol. 44, no. 6, pp. 409-414, 2013.

[8] D. S. Silverberg, A. Oksenberg, and A. Iaina, "Sleep related breathing disorders are common contributing factors to the production of essential hypertension but are neglected, underdiagnosed, and undertreated," The American Journal of Hypertension, vol. 10, no. 12, part 1, pp. 1319-1325, 1997.

[9] A. J. Atkinson, W. A. Colburn, V. G. DeGruttola et al., "Biomarkers and surrogate endpoints: preferred definitions and conceptual framework," Clinical Pharmacology \& Therapeutics, vol. 69, no. 3, pp. 89-95, 2001.

[10] J. L. Shih and A. Malhotra, "Could vitamins be helpful to patients with sleep apnea?" Chest, vol. 139, no. 2, pp. 237-238, 2011.

[11] J. M. Mullington, M. Haack, M. Toth, J. M. Serrador, and H. K. Meier-Ewert, "Cardiovascular, inflammatory, and metabolic consequences of sleep deprivation," Progress in Cardiovascular Diseases, vol. 51, no. 4, pp. 294-302, 2009.

[12] S. R. Patel, X. Zhu, A. Storfer-Isser et al., "Sleep duration and biomarkers of inflammation," Sleep, vol. 32, no. 2, pp. 200-204, 2009. 
[13] V. Mohamed-Ali, S. Goodrick, A. Rawesh et al., "Subcutaneous adipose tissue releases interleukin-6, but not tumor necrosis factor- $\alpha$, in vivo," The Journal of Clinical Endocrinology and Metabolism, vol. 82, no. 12, pp. 4196-4200, 1997.

[14] J. M. Bruun, S. B. Pedersen, and B. Richelsen, "Regulation of interleukin 8 production and gene expression in human adipose tissue in vitro," The Journal of Clinical Endocrinology and Metabolism, vol. 86, no. 3, pp. 1267-1273, 2001.

[15] G. S. Hotamisligil, P. Arner, J. F. Caro, R. L. Atkinson, and B. M. Spiegelman, "Increased adipose tissue expression of tumor necrosis factor- $\alpha$ in human obesity and insulin resistance," The Journal of Clinical Investigation, vol. 95, no. 5, pp. 2409-2415, 1995.

[16] M. M. R. Alvarado and C. S. Roitz, "Relation of serum levels of C-reactive protein to anthropometric meaurements; a sustematic review of studies in South America," Nutricion Hospitalaria, vol. 27, no. 4, pp. 971-977, 2012.

[17] V. Pasceri, J. Chang, J. T. Willerson, and E. T. H. Yeh, "Modulation of C-reactive protein-mediated monocyte chemoattractant protein-1 induction in human endothelial cells by antiatherosclerosis drugs," Circulation, vol. 103, no. 21, pp. 25312534, 2001.

[18] P. M. Ridker, J. E. Buring, J. Shih, M. Matias, and C. H. Hennekens, "Prospective study of C-reactive protein and the risk of future cardiovascular events among apparently healthy women," Circulation, vol. 98, no. 8, pp. 731-733, 1998.

[19] C. Heeschen, C. W. Hamm, J. Bruemmer, and M. L. Simoons, "Predictive value of C-reactive protein and troponin $\mathrm{T}$ in patients with unstable angina: a comparative analysis," Journal of the American College of Cardiology, vol. 35, no. 6, pp. 1535$1542,2000$.

[20] J. Sahlman, K. Miettinen, K. Peuhkurinen et al., “The activation of the inflammatory cytokines in overweight patients with mild obstructive sleep apnoea: Sleep apnea and inflammation," Journal of Sleep Research, vol. 19, no. 2, pp. 341-348, 2010.

[21] A. S. M. Shamsuzzaman, M. Winnicki, P. Lanfranchi et al., "Elevated C-reactive protein in patients with obstructive sleep apnea," Circulation, vol. 105, no. 21, pp. 2462-2464, 2002.

[22] M. Hayashi, K. Fujimoto, K. Urushibata, A. Takamizawa, O. Kinoshita, and K. Kubo, "Hypoxia-sensitive molecules may modulate the development of atherosclerosis in sleep apnoea syndrome," Respirology, vol. 11, no. 1, pp. 24-31, 2006.

[23] P. Steiropoulos, N. Papanas, E. Nena et al., "Inflammatory markers in middle-aged obese subjects: does obstructive sleep apnea syndrome play a role?" Mediators of Inflammation, vol. 2010, Article ID 675320, 6 pages, 2010.

[24] S. F. Guven, M. H. Turkkani, B. Ciftci, T. U. Ciftci, and Y. Erdogan, "The relationship between high-sensitivity C-reactive protein levels and the severity of obstructive sleep apnea," Sleep and Breathing, vol. 16, no. 1, pp. 217-221, 2012.

[25] T. S. Hall, T. E. Herrscher, P. Jarolim et al., "Myeloid-related protein-8/14 and C-reactive protein in individuals evaluated for obstructive sleep apnea," Sleep Medicine, vol. 15, pp. 762-768, 2014.

[26] T. Yokoe, K. Minoguchi, H. Matsuo et al., "Elevated levels of Creactive protein and interleukin-6 in patients with obstructive sleep apnea syndrome are decreased by nasal continuous positive airway pressure," Circulation, vol. 107, no. 8, pp. 11291134, 2003.

[27] P. Steiropoulos, V. Tsara, E. Nena et al., "Effect of continuous positive airway pressure treatment on serum cardiovascular risk factors in patients with obstructive sleep apnea-hypopnea syndrome," Chest, vol. 132, no. 3, pp. 843-851, 2007.

[28] M. Kohler, L. Ayers, J. C. T. Pepperell et al., "Effects of continuous positive airway pressure on systemic inflammation in patients with moderate to severe obstructive sleep apnoea: a randomised controlled trial," Thorax, vol. 64, no. 1, pp. 67-73, 2009.

[29] A. Baessler, R. Nadeem, M. Harvey et al., "Treatment for sleep apnea by continuous positive airway pressure improves levels of inflammatory markers-a meta-analysis," Journal of Inflammation, vol. 10, no. 1, p. 13, 2013.

[30] R. Nadeem, J. Molnar, E. M. Madbouly et al., "Serum inflammatory markers in obstructive sleep apnea: a meta-analysis," Journal of Clinical Sleep Medicine, vol. 9, no. 10, pp. 1003-1012, 2013.

[31] C. Guilleminault, C. Kirisoglu, and M. M. Ohayon, "C-reactive protein and sleep-disordered breathing," Sleep, vol. 27, no. 8, pp. 1507-1511, 2004.

[32] S. Ryan, G. M. Nolan, E. Hannigan, S. Cunningham, C. Taylor, and W. T. McNicholas, "Cardiovascular risk markers in obstructive sleep apnoea syndrome and correlation with obesity," Thorax, vol. 62, no. 6, pp. 509-514, 2007.

[33] E. S. Arnardottir, G. Maislin, R. J. Schwab et al., “The interaction of obstructive sleep apnea and obesity on the inflammatory markers C-reactive protein and interleukin-6: the Icelandic Sleep Apnea Cohort,” Sleep, vol. 35, no. 7, pp. 921-932, 2012.

[34] H. T. Idriss and J. H. Naismith, "TNF alpha and the TNF receptor superfamily: structure-function relationship(s)," Microscopy Research and Technique, vol. 50, no. 3, pp. 184-195, 2000.

[35] A. N. Vgontzas, D. A. Papanicolaou, E. O. Bixler, A. Kales, K. Tyson, and G. P. Chrousos, "Elevation of plasma cytokines in disorders of excessive daytime sleepiness: role of sleep disturbance and obesity," Journal of Clinical Endocrinology and Metabolism, vol. 82, no. 5, pp. 1313-1316, 1997.

[36] K. Minoguchi, T. Tazaki, T. Yokoe et al., "Elevated production of tumor necrosis factor- $\alpha$ by monocytes in patients with obstructive sleep apnea syndrome," Chest, vol. 126, no. 5, pp. 1473-1479, 2004.

[37] A. Kanbay, O. Kokturk, T. U. Ciftci, Y. Tavil, and N. Bukan, "Comparison of serum adiponectin and tumor necrosis factoralpha levels between patients with and without obstructive sleep apnea syndrome," Respiration, vol. 76, no. 3, pp. 324-330, 2008.

[38] H. Liu, J. Liu, S. Xiong, G. Shen, Z. Zhang, and Y. Xu, “The change of interleukin- 6 and tumor necrosis factor in patients with obstructive sleep apnea syndrome," Journal of Tongji Medical University, vol. 20, no. 3, pp. 200-202, 2000.

[39] T. U. Ciftci, O. Kokturk, N. Bukan, and A. Bilgihan, "The relationship between serum cytokine levels with obesity and obstructive sleep apnea syndrome," Cytokine, vol. 28, no. 2, pp. 87-91, 2004.

[40] M. M. Ciccone, P. Scicchitano, A. Zito et al., "Correlation between inflammatory markers of atherosclerosis and carotid intima-media thickness in obstructive sleep apnea," Molecules, vol. 19, no. 2, pp. 1651-1662, 2014.

[41] P. Steiropoulos, I. Kotsianidis, E. Nena et al., "Long-term effect of continuous positive airway pressure therapy on inflammation markers of patients with obstructive sleep apnea syndrome," Sleep, vol. 32, no. 4, pp. 537-543, 2009.

[42] A. Hegglin, O. D. Schoch, W. Korte, K. Hahn, C. Hürny, and T. Münzer, "Eight months of continuous positive airway pressure (CPAP) decrease tumor necrosis factor alpha (TNFA) in men 
with obstructive sleep apnea syndrome," Sleep and Breathing, vol. 16, no. 2, pp. 405-412, 2012.

[43] S. Imagawa, Y. Yamaguchi, K. Ogawa et al., "Interleukin-6 and tumor necrosis factor-alpha in patients with obstructive sleep apnea-hypopnea syndrome," Respiration, vol. 71, no. 1, pp. 2429, 2004.

[44] L. Guasti, F. Marino, M. Cosentino et al., "Cytokine production from peripheral blood mononuclear cells and polymorphonuclear leukocytes in patients studied for suspected obstructive sleep apnea," Sleep \& Breathing, vol. 15, no. 1, pp. 3-11, 2011.

[45] G. Fantuzzi, "Adipose tissue, adipokines, and inflammation," The Journal of Allergy and Clinical Immunology, vol. 115, no. 5, pp. 911-920, 2005.

[46] J. C. Hedges, C. A. Singer, and W. T. Gerthoffer, "Mitogenactivated protein kinases regulate cytokine gene expression in human airway myocytes," The American Journal of Respiratory Cell and Molecular Biology, vol. 23, no. 1, pp. 86-94, 2000.

[47] N. Hirani, F. Antonicelli, R. M. Strieter, M. S. Wiesener, C. Haslett, and S. C. Donnelly, "The regulation of interleukin8 by hypoxia in human macrophages-a potential role in the pathogenesis of the acute respiratory distress syndrome (ARDS)," Molecular Medicine, vol. 7, no. 10, pp. 685-697, 2001.

[48] E. Ohga, T. Tomita, H. Wada, H. Yamamoto, T. Nagase, and Y. Ouchi, "Effects of obstructive sleep apnea on circulating ICAM1, IL-8, and MCP-1," Journal of Applied Physiology, vol. 94, no. 1, pp. 179-184, 2003.

[49] J.-I. Oyama, H. Yamamoto, T. Maeda, A. Ito, K. Node, and N. Makino, "Continuous positive airway pressure therapy improves vascular dysfunction and decreases oxidative stress in patients with the metabolic syndrome and obstructive sleep apnea syndrome," Clinical Cardiology, vol. 35, no. 4, pp. 231-236, 2012.

[50] M. A. Alzoghaibi and A. S. BaHammam, "Lipid peroxides, superoxide dismutase and circulating IL-8 and GCP-2 in patients with severe obstructive sleep apnea: a pilot study," Sleep \& Breathing, vol. 9, no. 3, pp. 119-126, 2005.

[51] R. Tamisier, J. L. Pépin, J. Rémy et al., "14 nights of intermittent hypoxia elevate daytime blood pressure and sympathetic activity in healthy humans," The European Respiratory Journal, vol. 37, no. 1, pp. 119-128, 2011.

[52] J. S. Yudkin, M. Kumari, S. E. Humphries, and V. MohamedAli, "Inflammation, obesity, stress and coronary heart disease: is interleukin-6 the link?” Atherosclerosis, vol. 148, no. 2, pp. 209214, 2000.

[53] J.-P. Bastard, M. Maachi, C. Lagathu et al., "Recent advances in the relationship between obesity, inflammation, and insulin resistance," European Cytokine Network, vol. 17, no. 1, pp. 4-12, 2006.

[54] J. N. Fain, A. K. Madan, M. L. Hiler, P. Cheema, and S. W. Bahouth, "Comparison of the release of adipokines by adipose tissue, adipose tissue matrix, and adipocytes from visceral and subcutaneous abdominal adipose tissues of obese humans," Endocrinology, vol. 145, no. 5, pp. 2273-2282, 2004.

[55] M. T. Maeder, W. Strobel, and M. Christ, "Comprehensive biomarker profiling in patients with obstructive sleep apnea," Clinical Biochemistry, 2014.

[56] R. Ross, "The pathogenesis of atherosclerosis: a perspective for the 1990s," Nature, vol. 362, no. 6423, pp. 801-809, 1993.

[57] J. S. Pober, M. A. Gimbrone Jr., L. A. Lapierre et al., "Overlapping patterns of activation of human endothelial cells by interleukin 1, tumor necrosis factor, and immune interferon," Journal of Immunology, vol. 137, no. 6, pp. 1893-1896, 1986.
[58] A. Amberger, C. Maczek, G. Jurgens et al., "Co-expression of ICAM-1, VCAM-1, ELAM-1 and Hsp60 in human arterial and venous endothelial cells in response to cytokines and oxidized low-density lipoproteins," Cell Stress \& Chaperones, vol. 2, no. 2, pp. 94-103, 1997.

[59] C. W. Smith, R. Rothlein, B. J. Hughes et al., "Recognition of an endothelial determinant for CD18-dependent human neutrophil adherence and transendothelial migration," The Journal of Clinical Investigation, vol. 82, no. 5, pp. 1746-1756, 1988.

[60] I. Ginis, S. J. Mentzer, and D. V. Faller, "Hypoxia induces lymphocyte adhesion to human mesenchymal cells via an LFA1-dependent mechanism," The American Journal of PhysiologyCell Physiology, vol. 264, no. 3, part 1, pp. C617-C624, 1993.

[61] S. Cofta, E. Wysocka, S. Dziegielewska-Gesiak et al., "Plasma selectins in patients with obstructive sleep apnea," Advances in Experimental Medicine and Biology, vol. 756, pp. 113-119, 2013.

[62] D. Testelmans, R. Tamisier, G. Barone-rochette et al., "Profile of circulating cytokines: impact of OSA, obesity and acute cardiovascular events," Cytokine, vol. 62, no. 2, pp. 210-216, 2013.

[63] J. S. Querido, A. W. Sheel, R. Cheema, S. V. Eeden, A. T. Mulgrew, and N. T. Ayas, "Effects of 10 days of modest intermittent hypoxia on circulating measures of inflammation in healthy humans," Sleep and Breathing, vol. 16, no. 3, pp. 657-662, 2012.

[64] A. Ursavas, M. Karadag, E. Rodoplu, A. Yilmaztepe, H. B. Oral, and R. O. Gozu, "Circulating ICAM-1 and VCAM-1 levels in patients with obstructive sleep apnea syndrome," Respiration, vol. 74, no. 5, pp. 525-532, 2007.

[65] E. Ohga, T. Nagase, T. Tomita et al., "Increased levels of circulating ICAM-1, VCAM-1, and L-selectin in obstructive sleep apnea syndrome," Journal of Applied Physiology, vol. 87, no. 1, pp. 10-14, 1999.

[66] A. A. El-Solh, M. J. Mador, P. Sikka, R. S. Dhillon, D. Amsterdam, and B. J. B. Grant, "Adhesion molecules in patients with coronary artery disease and moderate-to-severe obstructive sleep apnea," Chest, vol. 121, no. 5, pp. 1541-1547, 2002.

[67] K. Chin, T. Nakamura, K. Shimizu, M. Mishima, M. Miyasaka, and M. Ohi, "Effects of nasal continuous positive airway pressure on soluble cell adhesion molecules in patients with obstructive sleep apnea syndrome," The American Journal of Medicine, vol. 109, no. 7, pp. 562-567, 2000.

[68] P. M. Ridker, "Role of inflammatory biomarkers in prediction of coronary heart disease," The Lancet, vol. 358, no. 9286, pp. 946-948, 2001.

[69] L. Wilhelmsen, K. Svardsudd, K. Korsan-Bengtsen, B. Larsson, L. Welin, and G. Tibblin, "Fibrinogen as a risk factor for stroke and myocardial infarction," The New England Journal of Medicine, vol. 311, no. 8, pp. 501-505, 1984.

[70] T. E. Wessendorf, A. F. Thilmann, Y.-M. Wang, A. Schreiber, N. Konietzko, and H. Teschler, "Fibrinogen levels and obstructive sleep apnea in ischemic stroke," The American Journal of Respiratory and Critical Care Medicine, vol. 162, no. 6, pp. 20392042, 2000.

[71] L. Nobili, G. Schiavi, E. Bozano, F. de Carli, F. Ferrillo, and F. Nobili, "Morning increase of whole blood viscosity in obstructive sleep apnea syndrome," Clinical Hemorheology and Microcirculation, vol. 22, no. 1, pp. 21-27, 2000.

[72] R. Imoberdorf, P. J. Garlick, M. A. Mcnurlan et al., "Enhanced synthesis of albumin and fibrinogen at high altitude," Journal of Applied Physiology, vol. 90, no. 2, pp. 528-537, 2001.

[73] K. Chin, M. Ohi, H. Kita et al., "Effects of NCPAP therapy on fibrinogen levels in obstructive sleep apnea syndrome," The 
American Journal of Respiratory and Critical Care Medicine, vol. 153, no. 6, part 1, pp. 1972-1976, 1996.

[74] O. K. Basoglu, F. Sarac, S. Sarac, H. Uluer, and C. Yilmaz, "Metabolic syndrome, insulin resistance, fibrinogen, homocysteine, leptin, and C-reactive protein in obese patients with obstructive sleep apnea syndrome," Annals of Thoracic Medicine, vol. 6, no. 3, pp. 120-125, 2011.

[75] S. Steiner, T. Jax, S. Evers, M. Hennersdorf, A. Schwalen, and B. E. Strauer, "Altered blood rheology in obstructive sleep apnea as a mediator of cardiovascular risk," Cardiology, vol. 104, no. 2 , pp. 92-96, 2005.

[76] A. Shamsuzzaman, R. S. Amin, A. D. Calvin, D. Davison, and V. K. Somers, "Severity of obstructive sleep apnea is associated with elevated plasma fibrinogen in otherwise healthy patients," Sleep and Breathing, 2014.

[77] R. von Känel and J. E. Dimsdale, "Hemostatic alterations in patients with obstructive sleep apnea and the implications for cardiovascular disease," Chest, vol. 124, no. 5, pp. 1956-1967, 2003.

[78] A. G. Kaditis, E. I. Alexopoulos, E. Kalampouka et al., "Morning levels of fibrinogen in children with sleep-disordered breathing," European Respiratory Journal, vol. 24, no. 5, pp. 790-797, 2004.

[79] K. Krobot, H. W. Hense, P. Cremer, E. Eberle, and U. Keil, "Determinants of plasma fibrinogen: relation to body weight, waist-to-hip ratio, smoking, alcohol, age, and sex: results from the second MONICA Augsburg survey, 1989-1990," Arteriosclerosis and Thrombosis, vol. 12, no. 7, pp. 780-788, 1992.

[80] M. Valko, D. Leibfritz, J. Moncol, M. T. D. Cronin, M. Mazur, and J. Telser, "Free radicals and antioxidants in normal physiological functions and human disease," The International Journal of Biochemistry \& Cell Biology, vol. 39, no. 1, pp. 44-84, 2007.

[81] L. Lavie, "Oxidative stress-a unifying paradigm in obstructive sleep apnea and comorbidities," Progress in Cardiovascular Diseases, vol. 51, no. 4, pp. 303-312, 2009.

[82] J. M. McCord, "Oxygen-derived free radicals in postischemic tissue injury," The New England Journal of Medicine, vol. 312, no. 3, pp. 159-163, 1985.

[83] K. Katsoulis, T. Kontakiotis, D. Spanogiannis et al., "Total antioxidant status in patients with obstructive sleep apnea without comorbidities: the role of the severity of the disease," Sleep \& Breathing, vol. 15, no. 4, pp. 861-866, 2011.

[84] S. D. Lee, G. Ju, J.-A. Choi, J.-W. Kim, and I.-Y. Yoon, "The association of oxidative stress with central obesity in obstructive sleep apnea," Sleep and Breathing, vol. 16, no. 2, pp. 511-517, 2012.

[85] M. Simiakakis, F. Kapsimalis, E. Chaligiannis, S. Loukides, N. Sitaras, and M. Alchanatis, "Lack of effect of sleep apnea on oxidative stress in obstructive sleep apnea syndrome (OSAS) patients," PLoS ONE, vol. 7, no. 6, Article ID e39172, 2012.

[86] J. D. Morrow and L. J. Roberts, "The isoprostanes: unique bioactive products of lipid peroxidation," Progress in Lipid Research, vol. 36, no. 1, pp. 1-21, 1997.

[87] K. C. Tan, W.-S. Chow, J. C. Lam et al., "HDL dysfunction in obstructive sleep apnea," Atherosclerosis, vol. 184, no. 2, pp. 377382, 2006.

[88] A. Barceló, J. Piérola, M. De La Peña et al., "Free fatty acids and the metabolic syndrome in patients with obstructive sleep apnoea," European Respiratory Journal, vol. 37, no. 6, pp. 14181423, 2011.

[89] A. Alonso-Fernández, F. García-Río, M. A. Arias et al., "Effects of CPAP on oxidative stress and nitrate efficiency in sleep apnoea: a randomised trial," Thorax, vol. 64, no. 7, pp. 581-586, 2009.

[90] A. Svatikova, R. Wolk, L. O. Lerman et al., "Oxidative stress in obstructive sleep apnoea," European Heart Journal, vol. 26, no. 22, pp. 2435-2439, 2005.

[91] S. Tsimikas, P. Willeit, J. Willeit et al., "Oxidation-specific biomarkers, prospective 15-year cardiovascular and stroke outcomes, and net reclassification of cardiovascular events," Journal of the American College of Cardiology, vol. 60, no. 21, pp. 22182229, 2012.

[92] G. Mehmetcik, G. Ozdemirler, O. Kanbagli, G. Toker, and M. Uysal, "Age-related changes in plasma lipid peroxidation and antioxidant system in humans and rats," Archives of Gerontology and Geriatrics, vol. 25, no. 3, pp. 305-310, 1997.

[93] Z. Dorkova, D. Petrasova, A. Molcanyiova, M. Popovnakova, and R. Tkacova, "Effects of continuous positive airway pressure on cardiovascular risk profile in patients with severe obstructive sleep apnea and metabolic syndrome," Chest, vol. 134, no. 4, pp. 686-692, 2008.

[94] E. Vatansever, E. Surmen-Gur, A. Ursavas, and M. Karadag, "Obstructive sleep apnea causes oxidative damage to plasma lipids and proteins and decreases adiponectin levels," Sleep \& Breathing, vol. 15, no. 3, pp. 275-282, 2011.

[95] B. Jurado-Gámez, M. C. Fernandez-Marin, J. L. GómezChaparro et al., "Relationship of oxidative stress and endothelial dysfunction in sleep apnoea," The European Respiratory Journal, vol. 37, no. 4, pp. 873-879, 2011.

[96] A. Barcelo, C. Miralles, F. Barbe, M. Vila, S. Pons, and A. G. N. Agusti, "Abnormal lipid peroxidation in patients with sleep apnoea," European Respiratory Journal, vol. 16, no. 4, pp. 644$647,2000$.

[97] W. Jordan, S. Cohrs, D. Degner et al., "Evaluation of oxidative stress measurements in obstructive sleep apnea syndrome," Journal of Neural Transmission, vol. 113, no. 2, pp. 239-254, 2006.

[98] S. Cofta, E. Wysocka, S. Michalak, T. Piorunek, H. BaturaGabryel, and L. Torlinski, "Endothelium-derived markers and antioxidant status in the blood of obstructive sleep apnea males," European Journal of Medical Research, vol. 14, supplement 4, pp. 49-52, 2009.

[99] E. Baysal, S. Taysi, N. Aksoy et al., "Serum paraoxonase, arylesterase activity and oxidative status in patients with obstructive sleep apnea syndrome (OSAS)," European Review for Medical and Pharmacological Sciences, vol. 16, no. 6, pp. 770774, 2012.

[100] T. T. Bekci, M. Kayrak, A. Kiyici et al., "The association among lipoprotein-associated phospholipase A2 levels, total antioxidant capacity and arousal in male patients with OSA," International Journal of Medical Sciences, vol. 8, no. 5, pp. 369376,2011

[101] M. Ntalapascha, D. Makris, A. Kyparos et al., "Oxidative stress in patients with obstructive sleep apnea syndrome," Sleep \& Breathing, vol. 17, no. 2, pp. 549-555, 2013.

[102] B. Goswami, D. Tayal, N. Gupta, and V. Mallika, "Paraoxonase: a multifaceted biomolecule," Clinica Chimica Acta, vol. 410, no. 1-2, pp. 1-12, 2009.

[103] L. Lavie, A. Vishnevsky, and P. Lavie, "Evidence for lipid peroxidation in obstructive sleep apnea," Sleep, vol. 27, no. 1, pp. 123-128, 2004.

[104] L. Lavie, L. Dyugovskaya, O. Golan-Shany, and P. Lavie, "Heatshock protein 70: expression in monocytes of patients with sleep apnoea and association with oxidative stress and tumour 
necrosis factor- $\alpha$," Journal of Sleep Research, vol. 19, no. 1, pp. 139-147, 2010.

[105] H. K. Okur, Z. Pelin, M. Yuksel, and S. Yosunkaya, "Lipid peroxidation and paraoxonase activity in nocturnal cyclic and sustained intermittent hypoxia," Sleep \& Breathing, vol. 17, no. 1, pp. 365-371, 2013.

[106] K. Kotani, S. Kimura, K. Tsuzaki et al., "Reduced paraoxonase 1/arylesterase activity and its post-therapeutic increase in obstructive sleep apnea syndrome: a preliminary study," Clinica Chimica Acta, vol. 395, no. 1-2, pp. 184-185, 2008.

[107] A. N. Vgontzas, E. O. Bixler, and G. P. Chrousos, "Sleep apnea is a manifestation of the metabolic syndrome," Sleep Medicine Reviews, vol. 9, no. 3, pp. 211-224, 2005.

[108] N. M. Punjabi, J. D. Sorkin, L. I. Katzel, A. P. Goldberg, A. R. Schwartz, and P. L. Smith, "Sleep-disordered breathing and insulin resistance in middle-aged and overweight men," The American Journal of Respiratory and Critical Care Medicine, vol. 165, no. 5, pp. 677-682, 2002.

[109] S. N. Sökücü, L. Karasulu, L. Dalar et al., "Effect of hypoxia on glucose methabolism in nondiabetic patients with obstructive sleep apnea syndrome," Archivos de Bronconeumologia, vol. 49, no. 8, pp. 321-325, 2013.

[110] D. Koren, L. E. L. Katz, P. C. Brar, P. R. Gallagher, R. I. Berkowitz, and L. J. Brooks, "Sleep architecture and glucose and insulin homeostasis in obese adolescents," Diabetes Care, vol. 34, no. 11, pp. 2442-2447, 2011.

[111] A. Tamura, Y. Kawano, T. Watanabe, and J. Kadota, "Obstructive sleep apnea increases hemoglobin Alc levels regardless of glucose tolerance status," Sleep Medicine, vol. 13, no. 8, pp. 10501055, 2012.

[112] M. P. Hermans, S. A. Ahn, Y. P. Mahadeb, and M. F. Rousseau, "Sleep apnoea syndrome and 10-year cardiovascular risk in females with type 2 diabetes: relationship with insulin secretion and insulin resistance," Diabetes/Metabolism Research and Reviews, vol. 29, no. 3, pp. 227-234, 2013.

[113] P. Priou, M. le Vaillant, N. Meslier et al., "Independent association between obstructive sleep apnea severity and glycated hemoglobin in adults without diabetes," Diabetes Care, vol. 35, no. 9, pp. 1902-1906, 2012.

[114] N. Papanas, P. Steiropoulos, E. Nena et al., "HbAlc is associated with severity of obstructive sleep apnea hypopnea syndrome in nondiabetic men," Vascular Health and Risk Management, vol. 5, pp. 751-756, 2009.

[115] P. Steiropoulos, N. Papanas, E. Nena et al., "Markers of glycemic control and insulin resistance in non-diabetic patients with Obstructive Sleep Apnea Hypopnea Syndrome: does adherence to CPAP treatment improve glycemic control?" Sleep Medicine, vol. 10, no. 8, pp. 887-891, 2009.

[116] M. Chakhtoura and S. T. Azar, "Continuous positive airway pressure and type 2 diabetes mellitus," Diabetes \& Metabolic Syndrome: Clinical Research and Reviews, vol. 6, no. 3, pp. 176179, 2012.

[117] I. H. Iftikhar and R. P. Blankfield, "Effect of continuous positive airway pressure on hemoglobin $\mathrm{A}_{1 c}$ in patients with obstructive sleep apnea: a systematic review and meta-analysis," Lung, vol. 190, no. 6, pp. 605-611, 2012.

[118] D. Yang, Z. Liu, H. Yang, and Q. Luo, "Effects of continuous positive airway pressure on glycemic control and insulin resistance in patients with obstructive sleep apnea: a meta-analysis," Sleep \& Breathing, vol. 17, no. 1, pp. 33-38, 2013.

[119] L. Hecht, R. Möhler, and G. Meyer, "Effects of CPAP-respiration on markers of glucose metabolism in patients with obstructive sleep apnoea syndrome: a systematic review and meta-analysis," German Medical Science, vol. 9, article Doc20, 2011.

[120] J. M. Friedman, "Leptin and the regulation of body weigh," The Keio Journal of Medicine, vol. 60, no. 1, pp. 1-9, 2011.

[121] T. A. Hargens, S. G. Guill, A. S. Kaleth et al., "Insulin resistance and adipose-derived hormones in young men with untreated obstructive sleep apnea," Sleep \& Breathing, vol. 17, no. 1, pp. 403-409, 2013.

[122] F. Tokuda, Y. Sando, H. Matsui, H. Koike, and T. Yokoyama, "Serum levels of adipocytokines, adiponectin and leptin, in patients with obstructive sleep apnea syndrome," Internal Medicine, vol. 47, no. 21, pp. 1843-1849, 2008.

[123] J. M. Garcia, H. Sharafkhaneh, M. Hirshkowitz, R. Elkhatib, and A. Sharafkhaneh, "Weight and metabolic effects of CPAP in obstructive sleep apnea patients with obesity," Respiratory Research, vol. 12, article 80, 2011.

[124] M. Sánchez-de-la-Torre, O. Mediano, A. Barcelo et al., "The influence of obesity and obstructive sleep apnea on metabolic hormones," Sleep and Breathing, vol. 16, no. 3, pp. 649-656, 2012.

[125] R. Vettor, G. Milan, M. Rossato, and G. Federspil, "Review article: adipocytokines and insulin resistance," Alimentary Pharmacology \& Therapeutics, vol. 22, supplement 2, pp. 3-10, 2005.

[126] J. C. Lam, A. Xu, S. Tam et al., "Hypoadiponectinemia is related to sympathetic activation and severity of obstructive sleep apnea," Sleep, vol. 31, no. 12, pp. 1721-1727, 2008.

[127] Y. Nakagawa, K. Kishida, S. Kihara et al., "Nocturnal reduction in circulating adiponectin concentrations related to hypoxic stress in severe obstructive sleep apnea-hypopnea syndrome," American Journal of Physiology-Endocrinology and Metabolism, vol. 294, no. 4, pp. E778-E784, 2008.

[128] X.-L. Zhang, K.-S. Yin, H. Wang, and S. Su, "Serum adiponectin levels in adult male patients with obstructive sleep apnea hypopnea syndrome," Respiration, vol. 73, no. 1, pp. 73-77, 2006.

[129] J. Kim, C. H. Lee, C. S. Park, B. G. Kim, S. W. Kim, and J. H. Cho, "Plasma levels of MCP-1 and adiponectin in obstructive sleep apnea syndrome," Archives of Otolaryngology-Head and Neck Surgery, vol. 136, no. 9, pp. 896-899, 2010.

[130] I. A. Harsch, H. Wallaschofski, C. Koebnick et al., "Adiponectin in patients with obstructive sleep apnea syndrome: course and physiological relevance," Respiration, vol. 71, no. 6, pp. 580-586, 2004.

[131] A. M. J. de Lima, C. M. R. Franco, C. M. M. B. de Castro, A. D. A. Bezerra, L. Ataíde Jr., and A. Halpern, "Effects of nasal continuous positive airway pressure treatment on oxidative stress and adiponectin levels in obese patients with obstructive sleep apnea," Respiration, vol. 79, no. 5, pp. 370-376, 2010.

[132] X.-L. Zhang, K.-S. Yin, C. Li, E.-Z. Jia, Y.-Q. Li, and Z.-F. Gao, "Effect of continuous positive airway pressure treatment on serum adiponectin level and mean arterial pressure in male patients with obstructive sleep apnea syndrome," Chinese Medical Journal, vol. 120, no. 17, pp. 1477-1481, 2007.

[133] M. Degawa-Yamauchi, J. E. Bovenkerk, B. E. Juliar et al., "Serum resistin (FIZZ3) protein is increased in obese humans," The Journal of Clinical Endocrinology and Metabolism, vol. 88, no. 11, pp. 5452-5455, 2003.

[134] J. V. Silha, M. Krsek, J. V. Skrha, P. Sucharda, B. L. G. Nyomba, and L. J. Murphy, "Plasma resistin, adiponectin and leptin levels in lean and obese subjects: correlations with insulin resistence," European Journal of Endocrinology, vol. 149, no. 4, pp. 331-335, 2003. 
[135] Y. Yamamoto, S. Fujiuchi, M. Hiramatsu et al., "Resistin is closely related to systemic inflammation in obstructive sleep apnea," Respiration, vol. 76, no. 4, pp. 377-385, 2008.

[136] I. A. Harsch, C. Koebnick, H. Wallaschofski et al., "Resistin levels in patients with obstructive sleep apnoea syndrome-the link to subclinical inflammation?" Medical Science Monitor, vol. 10, no. 9, pp. CR510-CR515, 2004.

[137] S. Yim-Yeh, S. Rahangdale, A. T. D. Nguyen et al., "Vascular dysfunction in obstructive sleep apnea and type 2 diabetes mellitus," Obesity, vol. 19, no. 1, pp. 17-22, 2011.

[138] C. M. Dollery, J. R. McEwan, and A. M. Henney, "Matrix metalloproteinases and cardiovascular disease," Circulation Research, vol. 77, no. 5, pp. 863-868, 1995.

[139] S. Kondo, S. Kubota, T. Shimo et al., "Connective tissue growth factor increased by hypoxia may initiate angiogenesis in collaboration with matrix metalloproteinases," Carcinogenesis, vol. 23, no. 5, pp. 769-776, 2002.

[140] J. Volná, D. Kemlink, M. Kalousová et al., "Biochemical oxidative stress-related markers in patients with obstructive sleep apnea," Medical Science Monitor, vol. 17, no. 9, pp. CR491-CR497, 2011.

[141] T. Tazaki, K. Minoguchi, T. Yokoe et al., "Increased levels and activity of matrix metalloproteinase- 9 in obstructive sleep apnea syndrome," American Journal of Respiratory and Critical Care Medicine, vol. 170, no. 12, pp. 1354-1359, 2004.

[142] E. Vuralkan, M. Mutlu, I. H. Firat et al., "Changes in serum levels of MDA and MMP-9 after UPF in patients with OSAS," European Archives of Oto-Rhino-Laryngology, vol. 271, no. 5, pp. 1329-1334, 2014.

[143] N. Kondo, Y. Ishii, Y.-W. Kwon et al., "Redox-sensing release of human thioredoxin from $T$ lymphocytes with negative feedback loops," Journal of Immunology, vol. 172, no. 1, pp. 442-448, 2004.

[144] W. Zhou, S. Li, N. Wan, Z. Zhang, R. Guo, and B. Chen, "Effects of various degrees of oxidative stress induced by intermittent hypoxia in rat myocardial tissues," Respirology, vol. 17, no. 5, pp. 821-829, 2012.

[145] J. Kim, R. Bhattacharjee, E. Dayyat et al., "Increased cellular proliferation and inflammatory cytokines in tonsils derived from children with obstructive sleep apnea," Pediatric Research, vol. 66, no. 4, pp. 423-428, 2009.

[146] K.-I. Takahashi, K. Chin, H. Nakamura et al., "Plasma thioredoxin, a novel oxidative stress marker, in patients with obstructive sleep apnea before and after nasal continuous positive airway pressure," Antioxidants and Redox Signaling, vol. 10, no. 4, pp. 715-726, 2008.

[147] Q. Guo, Y. Wang, Q. Y. Li, M. Li, and H. Y. Wan, "Levels of thioredoxin are related to the severity of obstructive sleep apnea: based on oxidative stress concept," Sleep and Breathing, vol. 17, no. 1, pp. 311-316, 2013.

[148] Y. Özkan, E. Özkan, and B. Imşek, "Plasma total homocysteine and cysteine levels as cardiovascular risk factors in coronary heart disease," International Journal of Cardiology, vol. 82, no. 3, pp. 269-277, 2002.

[149] F. Cintra, S. Tufik, V. D’Almeida et al., "Cysteine: a potential biomarker for obstructive sleep apnea," Chest, vol. 139, no. 2, pp. 246-252, 2011.

[150] A. Kanbay and H. C. Hasanoglu, "A new prognostic marker for obstructive sleep apnea: hepcidin," Medical Hypotheses, vol. 69, no. 6, pp. 1381-1382, 2007.

[151] M. R. Bonsignore and A. Zito, "Metabolic effects of the obstructive sleep apnea syndrome and cardiovascular risk," Archives of Physiology and Biochemistry, vol. 114, no. 4, pp. 255-260, 2008.
[152] D. Gozal, S. Jortani, A. B. Snow et al., “Two-dimensional differential in-gel electrophoresis proteomic approaches reveal urine candidate biomarkers in pediatric obstructive sleep apnea," The American Journal of Respiratory and Critical Care Medicine, vol. 180, no. 12, pp. 1253-1261, 2009. 


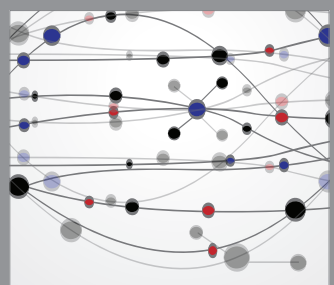

The Scientific World Journal
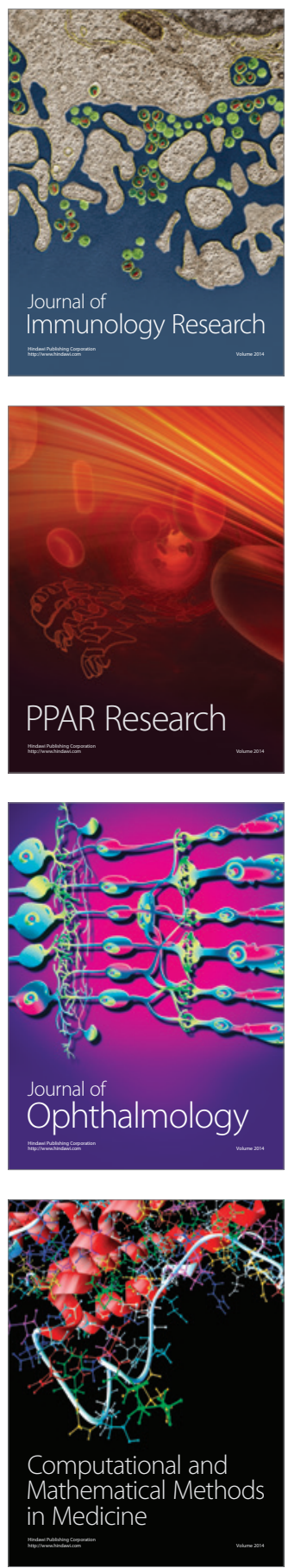

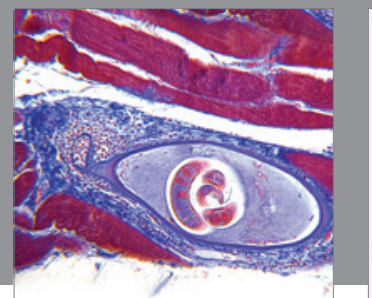

Gastroenterology

Research and Practice
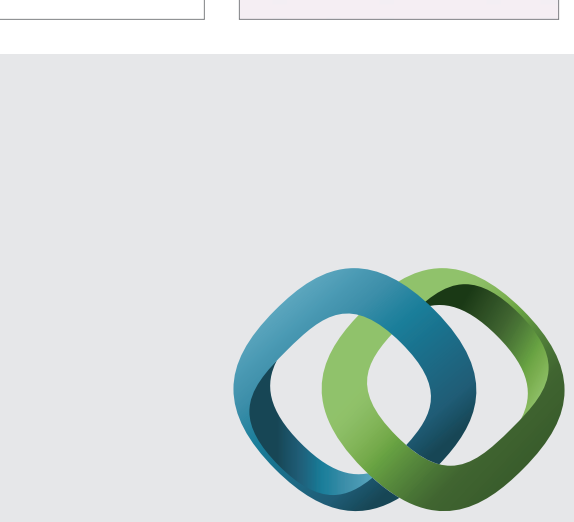

\section{Hindawi}

Submit your manuscripts at

http://www.hindawi.com
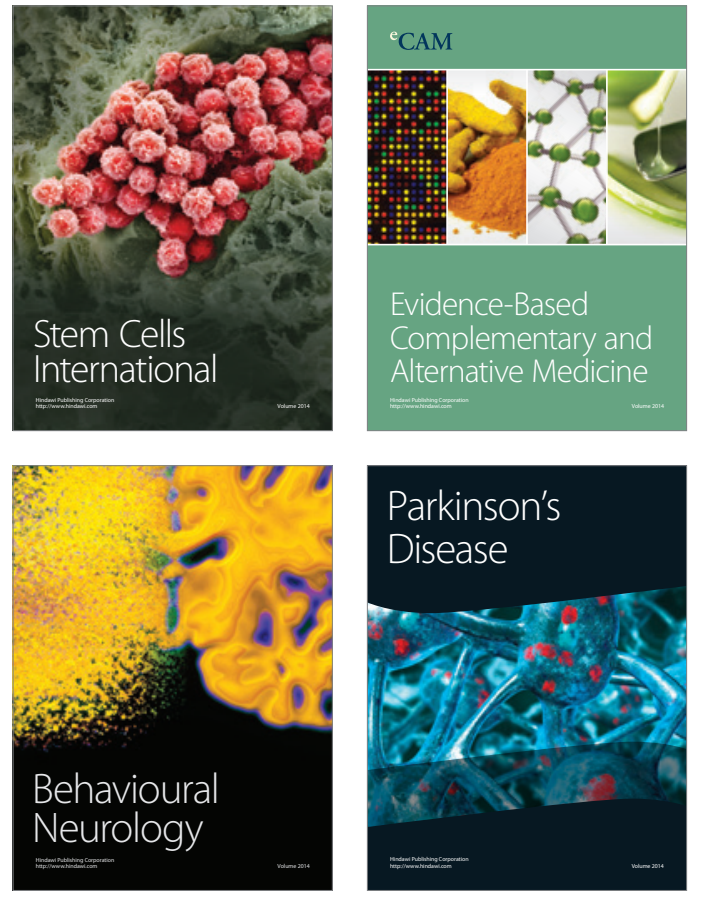
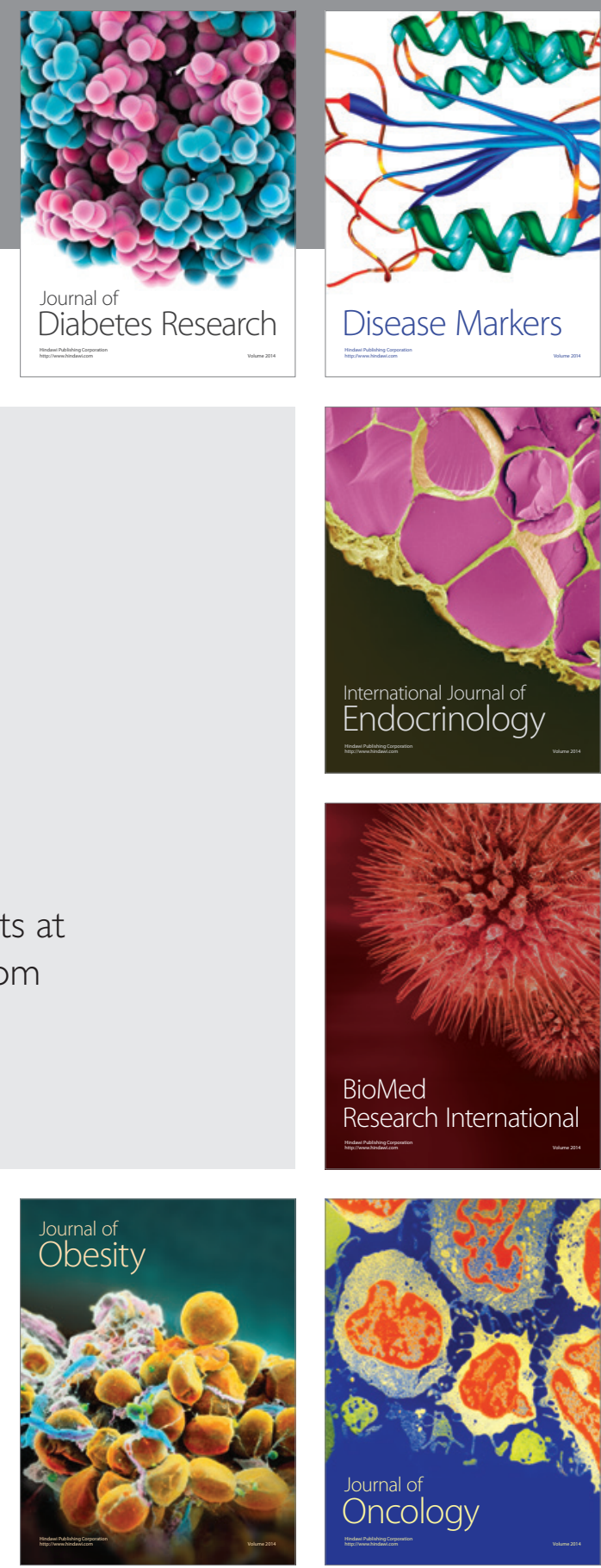

Disease Markers
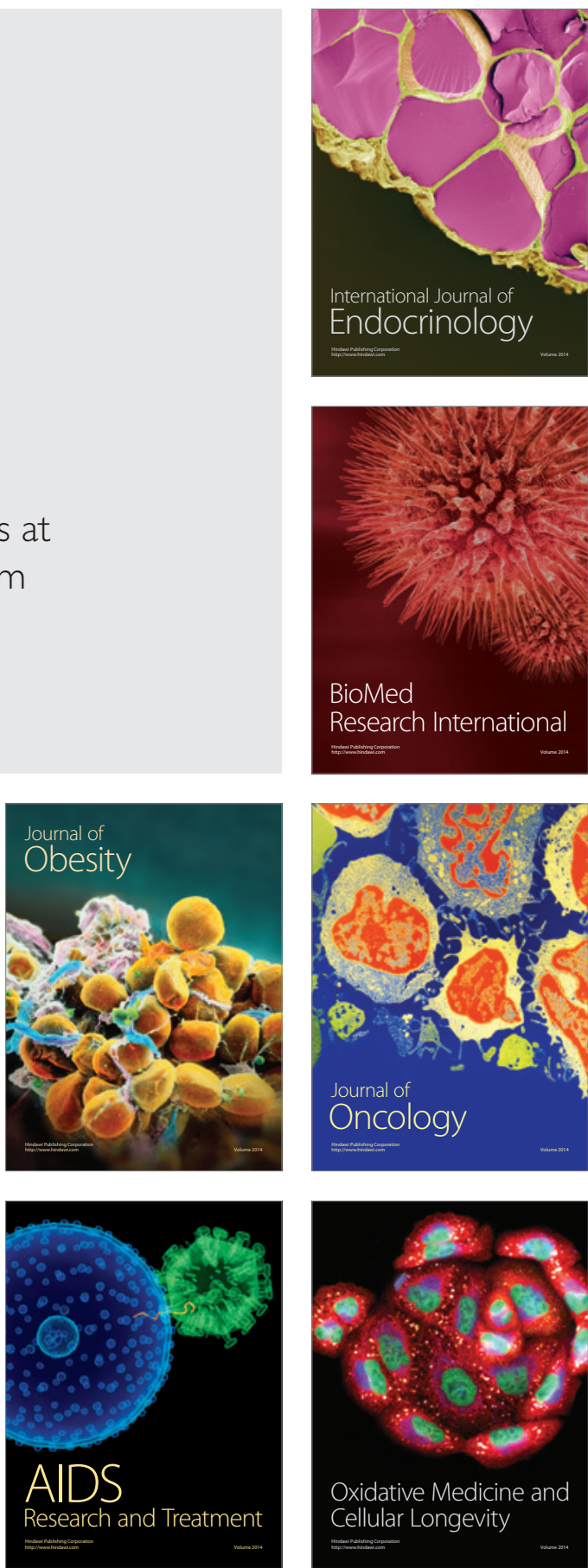